\title{
ALESSANDRA PRESTES
}

\section{ESTUDO COMPARATIVO DAS MATRIZES BOVINA E BUBALINA NA IDENTIFICAÇÃO DE microRNAS IMUMODULADORES FRENTE AO PROCESSO DE FERMENTAÇÃO POR BACTÉRIAS PROBIÓTICAS}

\author{
Versão original da Dissertação conforme resolução CoPGr 6018.
}

Dissertação apresentada para o Programa de Pós Graduação em Tecnologia de Alimentos da Faculdade de Ciências Farmacêuticas da Universidade de São Paulo para obtenção do Título de Mestre em Tecnologia Bioquímico Farmacêutica.

Área de concentração: Tecnologia de Alimentos

Orientadora: Prof ${ }^{\mathrm{a}}$. Dr ${ }^{\mathrm{a}}$. Cristina Stewart Bogsan

São Paulo 


\title{
UNIVERSIDADE DE SÃO PAULO
}

Faculdade de Ciências Farmacêuticas

Programa de Pós-Graduação em Tecnologia Bioquímico Farmacêutica Área de Tecnologia de Alimentos

\section{ESTUDO COMPARATIVO DAS MATRIZES BOVINA E BUBALINA NA IDENTIFICAÇÃO DE microRNAS IMUMODULADORES FRENTE AO PROCESSO DE FERMENTAÇÃO POR BACTÉRIAS PROBIÓTICAS}

\author{
Alessandra Prestes \\ Versão original da Dissertação conforme resolução CoPGr 6018. \\ Dissertação para obtenção do Título de Mestre \\ Orientadora: Prof ${ }^{a}$. Dr ${ }^{\mathrm{a}}$. Cristina Stewart Bogsan
}

São Paulo

2019 
Autorizo a reprodução e divulgação total ou parcial deste trabalho, por qualquer meio convencional ou eletronico, para fins de estudo e pesquisa, desde que citada a fonte.

Ficha Catalográfica elaborada eletronicamente pelo autor, utilizando o programa desenvolvido pela Seção Técnica de Informática do ICMC/USP e adaptado para a Divisão de Bb̈lioteca e Documentação do Conjunto das Quimicas da USP

Bỉbliotecária responsável pela orientação de catalogação da publicação: Marlene Aparecida Vieira - CRB - 8/5562

P936e Prestes, Alessandra

ESTUDO COMPARATIVO DAS MATRIZES BOVINA E BUBALINA NA IDENTIFICAÇĀO DE MICRORNAS

IMUMODULADORES PRENTE AO PROCESSO DE FERMENTAÇ̄̃o POR BACTÉRIAS PROBIÓTICAS / Alessandra Prestes. - São Paulo, 2019.

$74 \mathrm{p}$.

Dissertação (mestrado) - Paculdade de Ciências Farmacêtucicas da Universidade de São Paulo.

Departamento de Tecnologia Bioquimico-Parmacêtutica.

Orientador: Bogsan, Cristina

1. Matrizes bovina e bubalina. 2. fermentação. 3 . bactếrias probiótica. 4. miRNas imunomoduladores. I. T. II. Bogsan, Cristina, orientador. 
Alessandra Prestes

\section{ESTUDO COMPARATIVO DAS MATRIZES BOVINA E BUBALINA NA IDENTIFICAÇÃO DE MICRORNAS IMUMODULADORES FRENTE AO PROCESSO DE FERMENTAÇÃO POR BACTÉRIAS PROBIÓTICAS}

Comissão Julgadora da Dissertação/Tese para obtenção do Título de Mestre

Prof. Dr.

orientador/presidente

1o. examinador

2o. examinador

3o. examinador

4o. examinador

São Paulo, de de 2019. 


\section{DEDICATÓRIA}

Primeiramente, agradeço à Deus por todas as oportunidades que me propiciou em minha vida e por me dar saúde para conseguir finalizar essa etapa.

Agradeço a minha família, minha mãe Elisabeth Adelaide Prestes, em agradecimento especial por permanecer ao meu lado nos momentos mais díficeis e acreditar que minha carreira como Pesquisadora poderia se tornar realidade. Agradeço, minha irmã Juliana Prestes pela paciência e carinho comigo. Agradeço ao meu falecido pai Antônio Prestes Neto em intenção, pois acredito que nada acontece ao acaso e ele também fez parte da minha conquista. Agradeço a minha professora, Cristina Bogsan pela oportunidade de fazer parte da sua linha de pesquisa e acreditar em meu potencial para desenvolver o meu projeto em sua linha de pesquisa.

Agradeço a todos os funcionários e colegas de laboratório que colaboraram para que esse trabalho chegasse ao final.

Agradeço a Capes e Fapesp pelo auxílio finaceiro para que esse projeto se desenvolvesse. 


\section{AGRADECIMENTOS}

À Professora Suzana Marta Isay Saad pelos conselhos sempre muito úteis como parecerista do meu projeto e por preservação das áreas comuns do bloco de Tecnologia de Alimentos.

À Professora Carlota de Oliveira Rangel Yagui pela orientação do início ao final do mestrado.

Ao professor Mário Hirata por nos proporcionar a utilização de seu laboratório e principalmente sua aluna de doutorado Renata Caroline que colaborou com sua boa vontade e conhecimento.

Ao professor João Paulo Fabi por ceder o equipamento de Imunofluorescência e treinamento por seu aluno.

Às Professoras Juliana Neves Rodrigues Ract, Suzana Caetano da Silva Lannes, pelos auxílios técnicos prestados.

À todos os colegas de laboratório Mariana Mitiko Matsuo, Alexy, Victória Ananias de Oliveira Rolim, Emanuele, Regina, Aline, Marsia Dolores Serrano Sansón, Caroliny de Almeida Souza, Gabriel Moretti e Catarina Vezetiv Manfrinato pela força, auxílios e amizade que me prestaram.

Às queridas Rose Clélia Dedivitis, Elza Ferreira Silva, Tania Nogueira Martinez, pelo carinho e pelo auxilio que sempre nos prestam com amor e dedicação.

À Sueli Duarte, Irineu Ruel de Oliveira e Sandra Lara, por sempre nos receber com carinho e paciência e prestar os auxílios burocráticos necessários.

Aos técnicos, Nilton de Morais Bloisi, Alexandre Mariane Rodrigues, Anderson Franco Anselmo, Gledson Manso Guimarães, Ivani Aparecida Raphael pelo auxílio prestado nas técnicas e no uso de equipamentos.

À minha orientadora Professora Doutora Cristina Stewart Bittencourt Bogsan orientação acadêmica durante todo o mestrado e a oportunidade de fazer parte da sua linha de pesquisa. 
"Acredite que cada desafio constrói um castelo de conquistas" 
PRESTES, A. Estudo comparativo das matrizes bovina e bubalina na identificação de microRNAs imumoduladores frente ao processo de fermentação por bactérias probióticas [Dissertação]. São Paulo: Faculdade de Ciências Farmacêuticas, Universidade de São Paulo; 2019.

\section{RESUMO}

Introdução: Com o crescente aumento de hipersensibilidades alimentares e doenças do trato gastrintestinal, o mercado de lácteos vem ampliando a variedade de produtos com diferentes matrizes alimentares. A expansão da criação bubalina no país incentivou o desenvolvimento de produtos derivados do leite bubalino, os quais contém propriedades nutricionais e físico-químicas diferentes da matriz bovina, ganhando maior participação no atual mercado consumidor. As bactérias probióticas são capazes de modular a resposta imune inata e adaptativa de acordo com a cepa, matriz e tecnologia empregada no desenvolvimento do produto. Assim como a modulação imune também pode ser alterada de maneira epigenética por interferência da matriz alimentar empregada. Método: Sendo os microRNAs de leite e leite bubalino homólogos aos do leite humano, foram preparados leites fermentados em matriz bovina e bubalina usando a cepa Bifidobacterium animalis subsp. lactis HN019 com o intuito de identificar a diferença entre o perfil físco-químico, viabilidade da cepa probiótica utilizada, e presença de microRNAs imunomoduladores homólogos com o intuito de verificar se as modificações sofridas nas matrizes bovina e bubalina durante o processo de fermentação por bactérias probióticas teria interferência na presença de miRNAs imunomoduladores e na resposta imune de mucosa. Conclusão: Os resultados obtidos mostraram maior teor de proteínas, sólidos totais e gordura na matriz bubalina em relação a matriz bovina. Enquanto na matriz bubalina fermentada apresentou maior teor de ácidos graxos comparado a matriz bovina fermentada, o perfil de acidificação e pós acidificação foi semelhante em ambas as matrizes. O processo de fermentação em matrizes lácteas distintas, proporcionou modificação do perfil celular imunológico na mucosa intestinal, porém levou a destruição dos miRNAs do processamento térmico, identificando que esta modificação da resposta imune independe dos microRNAs homólogos estudados.

Palavras chave: Efeito Imunomodulador, miRNAs, Bifidobacterium animalis subsp. lactis, leite bovino, leite bubalino. 
PRESTES, A. Comparative study of bovine and buffalo matrices in the identification of immuno-modulatory microRNAs against the probiotic bacteria fermentation process [Dissertation]. São Paulo: Faculty of Pharmaceutical Sciences, University of São Paulo; 2019.

\begin{abstract}
Introduction: With the increasing increase of food hypersensitivity and diseases of the gastrointestinal tract, the dairy market has been increasing the variety of products with different food matrices. The expansion of buffalo breeding in the country encouraged the development of products derived from buffalo milk, which contain different nutritional and physicochemical properties of the bovine matrix, gaining greater participation in the current consumer market. Probiotic bacteria are able to modulate the innate and adaptive immune response according to the strain, matrix and technology employed in product development. Just as immune modulation can also be altered epigenetically by interference of the food matrix employed. Method: Since the microRNAs of milk and buffalo milk were homologous to those of human milk, fermented milks were prepared in bovine matrix and buffalo using the strain Bifidobacterium animalis subsp. lactis HN019 in order to identify the difference between the physico-chemical profile, viability of the probiotic strain used, and the presence of homologous immunomodulatory microRNAs in order to verify if the modifications suffered in the bovine and buffalo matrices during the fermentation process by probiotic bacteria would interfere with the presence of immunomodulatory miRNAs and the mucosal immune response. Conclusion: The results showed higher protein content, total solids and fat in the buffalo matrix in relation to the bovine matrix. While in the fermented buffalo matrix presented higher content of fatty acids compared to fermented bovine matrix, the profile of acidification and post acidification was similar in both matrices. The fermentation process in distinct milk matrices provided a modification of the immunological cell profile in the intestinal mucosa but led to the destruction of the miRNAs of the thermal processing, identifying that this modification of the immune response is independent of the homologous microRNAs studied.
\end{abstract}

Key words: Immunomodulatory effect, miRNAs, Bifidobacterium animalis subsp. lactis, bovine milk, buffalo milk. 


\section{LISTA DE ABREVIATURAS}

$\mathrm{Balb} / \mathrm{c}$

Linhagem de Camundongos Albinos

C1

Controle 1

$\mathrm{C} 2$

Controle 2

Controle $\mathrm{C} 1$

Leite integral bovino

Controle C2

Leite integral bubalino

FCF - USP

Faculdade de Ciências Farmacêuticas da USP

GABA

Ácido Gama-aminobutírico

$\operatorname{Ig} \mathrm{A}$

Imunoglobulina A

$\operatorname{IgD}$

Imunoglobulina D

$\operatorname{IgM}$

Imunoglobulina $\mathrm{M}$

LPFB

Leite probiótico fermentado em matriz bubalina

LPFV

Leite probiótico fermentado em matriz bovina

CLA

Ácido Linoleico Conjugado

$\mathrm{miR}$

MicroRNA

MiRNA

MicroRNA

mRNA

RNA mensageiro

NK

Célula Natural Killer

RNA

Ácido Ribonucleico

RT-qPCR

Reverse Transcription Polymerase chain reaction quantitative real time

Subsp

Subespecie

tf

Tempo de fermentação final

TGI

Trato Gastrointestinal

TLR

Toll-like receptor

$t_{v \max }$

Tempo no qual se atinge a velocidade máxima

USP

Universidade de São Paulo

UV

Ultravioleta

$\mathrm{V}_{\max }$

Velocidade Máxima 


\section{LISTA DE SÍMBOLOS}

$\begin{array}{ll}{ }^{\circ} \mathrm{C} & \text { Graus Centígrados } \\ \% & \text { Porcentagem } \\ \mathrm{g} & \text { Gramas } \\ \mathrm{h} & \text { Horas } \\ \mathrm{mm} & \text { Milímetro } \\ \mathrm{UFC} / \mathrm{mL} & \text { Unidades Formadoras de colônia por mililitro } \\ \mathrm{UFC} / \mathrm{g} & \text { Unidades formadoras de colônias por grama de produto } \\ \mu \mathrm{L} & \text { Microlitros } \\ \mathrm{CO} & \\ \mathrm{RCA} & \text { Dióxido de Carbono } \\ \mathrm{min} & \text { Reinforced Clostridium agar } \\ \mathrm{s} & \text { Minuto } \\ \mathrm{rpm} & \text { Segundos } \\ \mathrm{pH} & \text { Rotação por minuto } \\ \mathrm{BSA} & \text { Potencial hidrogenionico } \\ \mathrm{Cy}-5 & \text { Albumina de Soro Bovino } \\ \mathrm{FITC} & \text { R-ficoeritrina-Cianina5 } \\ \mathrm{R}-\mathrm{PE} & \text { Isotiocianato de Fluorosceína } \\ \mathrm{PBS} & \text { R-ficoeritrina } \\ \mathrm{H}^{+} & \text {Nolução Tampão de Fosfato de Sódio } \\ \mathrm{nm} & \end{array}$




\section{LISTA DE FIGURAS}

\begin{tabular}{|c|c|c|}
\hline Figura 1 & Mecanismos de ação dos probióticos & 26 \\
\hline Figura 2 & Biogênese do MicroRNA & 30 \\
\hline Figura 3 & Mecanismo de Ação exossoma e célula receptora... & 31 \\
\hline Figura 4 & Desenho Experimental..... & 37 \\
\hline Figura 5 & $\begin{array}{l}\text { Comparação da metodologia Ekomilk e Adolfo Lutz nas } \\
\text { matrizes lácteas bovina e bubalina }(\mathrm{P}<0,05) \ldots\end{array}$ & 41 \\
\hline Figura 6 & $\begin{array}{l}\text { Curva de acidificação da fermentação por HN019 em matriz } \\
\text { bovina e bubalina............ }\end{array}$ & 41 \\
\hline Figura 7 & $\begin{array}{l}\text { Análise de } \mathrm{pH} \text { dos leites fermentados nos dias } 1,7,14 \text { e } 21 \\
\text { após a fermentação sob armazenamento a } 4^{\circ} \mathrm{C}(\mathrm{P}<0,5) \text {. }\end{array}$ & 42 \\
\hline Figura 8 & $\begin{array}{l}\text { Viabilidade da bactéria HN019 nas matrizes bovina e } \\
\text { bubalina nos dias } 1,14 \text { e } 21 \text { de armazenamento sob } \\
\text { refrigeração a } 4^{\circ} \mathrm{C}(\mathrm{P}<0,5) \ldots\end{array}$ & 43 \\
\hline Figura 9 & $\begin{array}{l}\text { Microscopia Óptica de muco cólon ascendente, grupo } 1 \text { - } \\
\text { leite, grupo } 2 \text { - leite fermentado, grupo } 3 \text { - leite bubalino e } \\
\text { grupo } 4 \text { - leite bubalino fermentado }(\mathrm{P}<0,05) \ldots\end{array}$ & 45 \\
\hline Figura 10 & $\begin{array}{l}\text { Histologia de colón ascendente de animais que consumiram leite } \\
\text { por } 14 \text { dias, coradas com azul oceano (A - bovino e C - bubalino) } \\
\text { mostrando produção de muco e contraste para quantificar em } \\
\text { porcentagem as porções de muco em vermelho, mucosa em } \\
\text { amarelo e luz em verde (B - bovino e D - bubalino). . }\end{array}$ & 46 \\
\hline Figura 11 & $\begin{array}{l}\text { Microscopia Óptica de muco cólon ascendente, grupo } 1 \text { - } \\
\text { leite, grupo } 2 \text { - leite fermentado, grupo } 3 \text { - leite bubalino e } \\
\text { grupo } 4 \text { - leite bubalino fermentado }(\mathrm{P}<0,05) \ldots\end{array}$ & 47 \\
\hline Figura 12 & $\begin{array}{l}\text { Histologia de colón ascendente de animais que consumiram leite } \\
\text { fermentado por } 14 \text { dias, coradas com azul oceano (A - bovino e C } \\
\text { - bubalino) mostrando produção de muco e contraste para } \\
\text { quantificar em porcentagem as porções de muco em vermelho, } \\
\text { mucosa em amarelo e luz em verde (B - bovino e D - bubalino). . }\end{array}$ & 47 \\
\hline Figura 13 & $\begin{array}{l}\text { Microscopia Óptica do infiltrtado celular de cólon } \\
\text { ascendente, grupo } 1 \text { - leite, grupo } 2 \text { - leite fermentado, } \\
\text { grupo } 3 \text { - leite bubalino e grupo } 4 \text { - leite bubalino } \\
\text { fermentado }(\mathrm{P}<0,05) \ldots\end{array}$ & 48 \\
\hline
\end{tabular}




\begin{tabular}{|c|c|c|}
\hline Figura 14 & $\begin{array}{l}\text { Histologia de colón ascendente de animais que consumiram leite } \\
\text { fermentado por } 14 \text { dias, coradas com HE (A- bovino e C- } \\
\text { bubalino) mostrando infiltrado celular sendo marcado em roxo o } \\
\text { núcleo das células, em amarelo a mucosa e em rosa a luz intestinal } \\
\text { (B - bovino e D - bubalino)... }\end{array}$ & 48 \\
\hline Figura 15 & $\begin{array}{l}\text { Microscopia Óptica do infiltrtado celular de cólon } \\
\text { ascendente, grupo } 1 \text { - leite, grupo } 2 \text { - leite fermentado, } \\
\text { grupo } 3 \text { - leite bubalino e grupo } 4 \text { - leite bubalino } \\
\text { fermentado }(\mathrm{P}<0,05) \text {.. }\end{array}$ & 49 \\
\hline Figura 16 & $\begin{array}{l}\text { Histologia de colón descendente de animais que consumiram leite } \\
\text { fermentado por } 14 \text { dias, coradas com HE (A- bovino e C- } \\
\text { bubalino) mostrando infiltrado celular sendo marcado em roxo o } \\
\text { núcleo das células, em amarelo a mucosa e em rosa a luz } \\
\text { intestinal.. }\end{array}$ & 49 \\
\hline Figura 17 & $\begin{array}{l}\text { Microscopia de fluorescencia do infiltrtado celular de cólon } \\
\text { ascendente marcado com anticorpo IgA+, grupo } 1 \text { - leite, } \\
\text { grupo } 2 \text { - leite fermentado, grupo } 3 \text { - leite bubalino e grupo } \\
4 \text { - leite bubalino fermentado }(\mathrm{P}<0,05) \text {. . }\end{array}$ & 50 \\
\hline Figura 18 & $\begin{array}{l}\text { Microscopia de fluorescencia do infiltrtado celular de cólon } \\
\text { ascendente marcado com anticorpo IgA+, grupo } 1 \text { - leite, } \\
\text { grupo } 2 \text { - leite fermentado, grupo } 3 \text { - leite bubalino e grupo } \\
4 \text { - leite bubalino fermentado }(\mathrm{P}<0,05) \text {. }\end{array}$ & 51 \\
\hline Figura 19 & $\begin{array}{l}\text { Microscopia de fluorescencia do infiltrtado celular de cólon } \\
\text { ascendente marcado com anticorpo } \operatorname{IgM}+\text {, grupo } 1 \text { - leite, } \\
\text { grupo } 2 \text { - leite fermentado, grupo } 3 \text { - leite bubalino e grupo } \\
4 \text { - leite bubalino fermentado }(\mathrm{P}<0,05) \text {. }\end{array}$ & 51 \\
\hline Figura 20 & $\begin{array}{l}\text { Microscopia de fluorescencia do infiltrtado celular de cólon } \\
\text { descendente marcado com anticorpo } \operatorname{IgM}+\text {, grupo } 1 \text { - leite, } \\
\text { grupo } 2 \text { - leite fermentado, grupo } 3 \text { - leite bubalino e grupo } \\
4 \text { - leite bubalino fermentado }(\mathrm{P}<0,05) \text {. . }\end{array}$ & 52 \\
\hline Figura 21 & $\begin{array}{l}\text { Microscopia de fluorescencia do infiltrtado celular de cólon } \\
\text { ascendente marcado com anticorpo } \mathrm{CD} 11 \mathrm{~b}+\text {, grupo } 1 \text { - leite, }\end{array}$ & 52 \\
\hline
\end{tabular}




\begin{tabular}{|l|l|l|}
\hline & $\begin{array}{l}\text { grupo 2 - leite fermentado, grupo 3 - leite bubalino e grupo } \\
4-\text { leite bubalino fermentado }(\mathrm{P}<0,05) .\end{array}$ & \\
\hline Figura 22 & $\begin{array}{l}\text { Microscopia de fluorescencia do infiltrtado celular de cólon } \\
\text { ascendente marcado com anticorpo CD11b+, grupo } 1-\text { leite, } \\
\text { grupo } 2-\text { leite fermentado, grupo 3 - leite bubalino e grupo } \\
4-\text { leite bubalino fermentado }(\mathrm{P}<0,05) .\end{array}$ & 53 \\
\hline
\end{tabular}




\section{LISTA DE TABELAS}

\begin{tabular}{|l|l|l|}
\hline Tabela 1 & $\begin{array}{l}\text { Parâmetros cinéticos da fermentação de matriz láctea } \\
\text { bubalina e bovina por cultura simples e cultura mista de } B .\end{array}$ & 42 \\
lactis (HN019) & $\begin{array}{l}\text { Porcentagem de células fagocíticas marcadas positivamente } \\
\text { para CD11b em duodeno de animais que consumiram leite } \\
\text { (grupo 1), leite fermentado (grupo 2), leite bubalino (grupo } \\
\text { 3) leite bubalino fermentado (grupo 4). }\end{array}$ & 54 \\
\hline Tabela 3 & $\begin{array}{l}\text { Porcentagem de células fagocíticas marcadas positivamente } \\
\text { para CD11c em duodeno de animais que consumiram leite } \\
\text { (grupo 1), leite fermentado (grupo 2), leite bubalino (grupo } \\
\text { 3) leite bubalino fermentado (grupo 4).. }\end{array}$ & 54 \\
\hline Tabela 4 & $\begin{array}{l}\text { Porcentagem de células T helper marcadas positivamente } \\
\text { para CD3 e CD4 e de células T citotóxicas marcadas } \\
\text { positivamente para CD3+ e CD8+ em duodeno de animais } \\
\text { que consumiram leite (grupo 1), leite fermentado (grupo 2), } \\
\text { leite bubalino (grupo 3) leite bubalino fermentado (grupo } \\
\text { 4).. }\end{array}$ & \\
\hline
\end{tabular}




\section{LISTA DE ANEXOS}

Anexo 1 - Certificado CEUA 


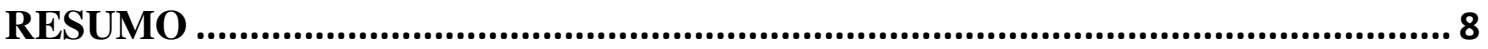

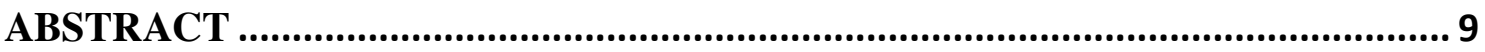

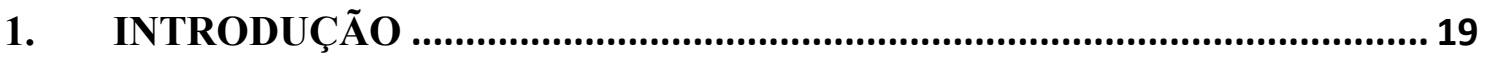

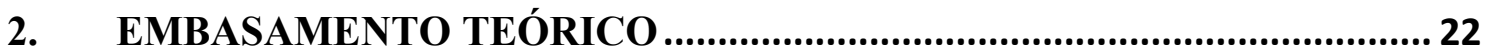

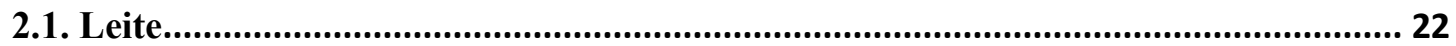

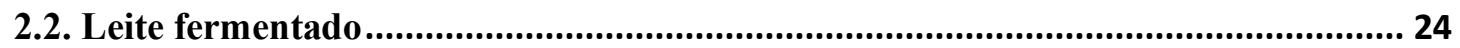

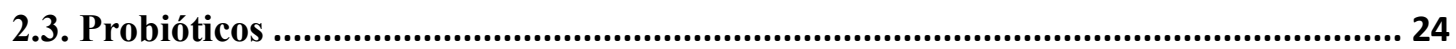

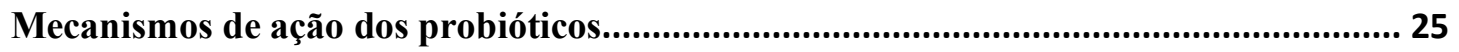

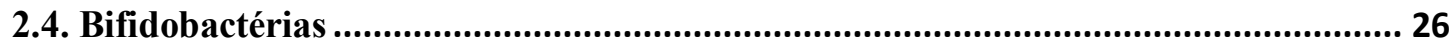

2.4.1. Bifidobacterium animalis subsp. lactis HOWARU HN019 ............................... 27

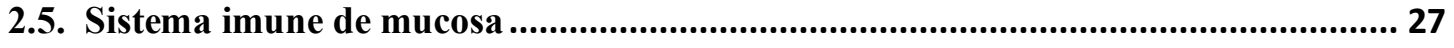

2.6. MicroRNA

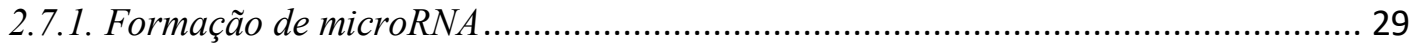

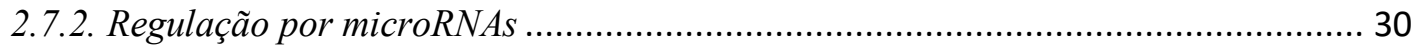

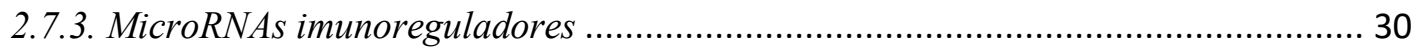

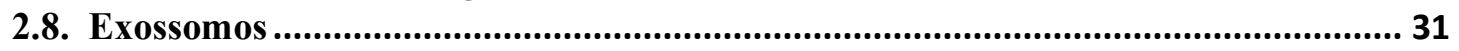

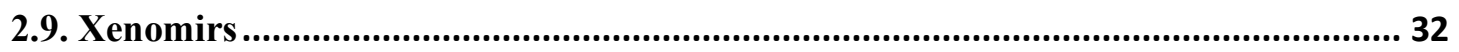

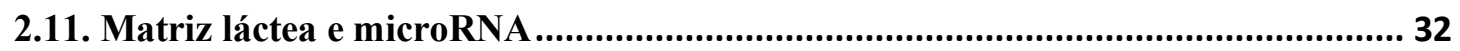

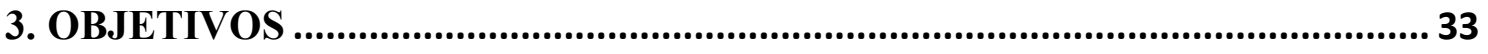

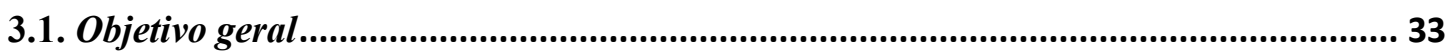

3.2. Objetivos específicos ............................................................................................................ 33

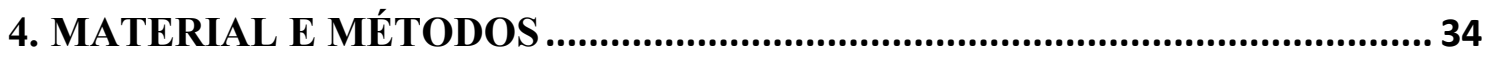

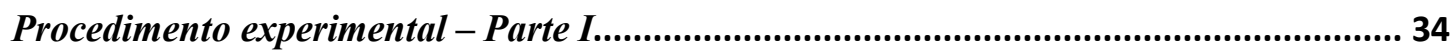

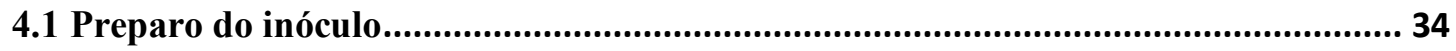

4.2 Fermentação .................................................................................................................. 34

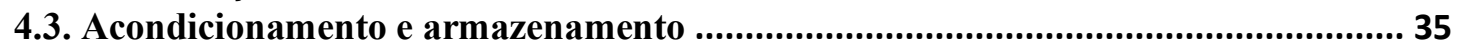

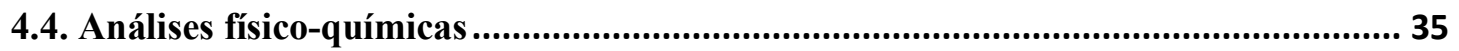

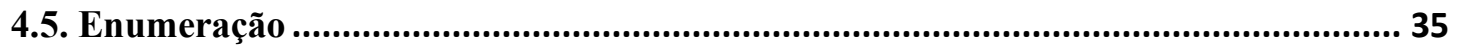

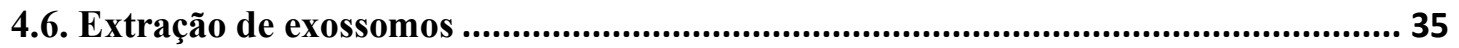

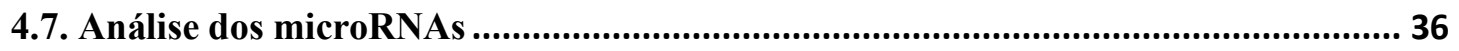

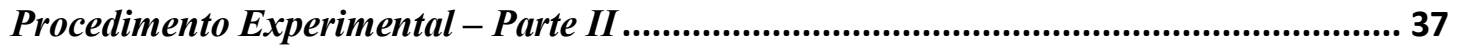

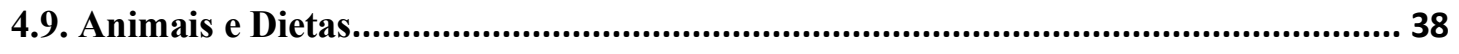

4.10. Análise do infiltrado linfocitário por corte histológico ............................................. 38

4.11. Análise da modulação imunológica celular no cólon por técnica de

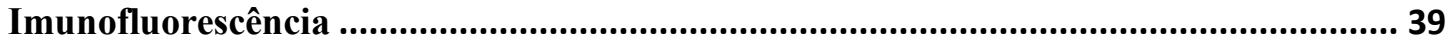

4.12. Análise da modulação imunológica celular no intestino delgado por técnica de citometria de fluxo..................................................................................................................... 39

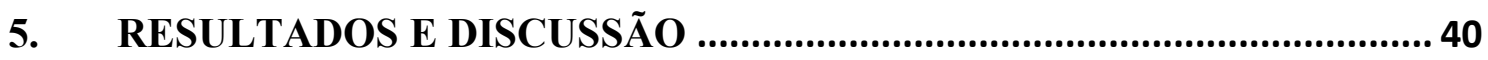

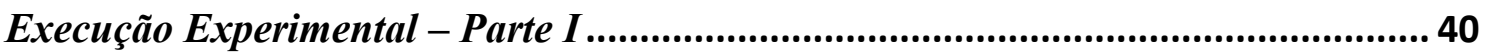

5.1. Comparação físico química das matrizes bovina e bubalina ....................................... 40

5.2. Desenvolvimento dos produtos lácteos - cinética de acidificação .............................. 41

5.3. Desenvolvimento dos produtos lácteos - análises microbiológicas............................... 43

5.4. Desenvolvimento de produtos lácteos - extração de exossomos ................................. 43 
5.5. Análise da expressão de miRNAs por PCR quantitativa em tempo real (RT-qPCR)

5.6. Análise histológica do infiltrado linfocitário por HE e do muco por Azul Oceano do cólon de camundongos. 45

5.7. Análise por imunofluorescencia do infiltrado linfocitário do cólon de camundongos. 50

5.8. Análise por citometria de fluxo do infiltrado linfocitário do cólon do camundongo.

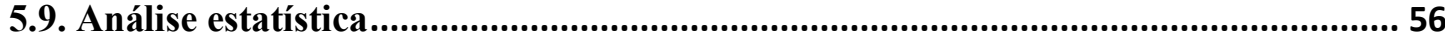

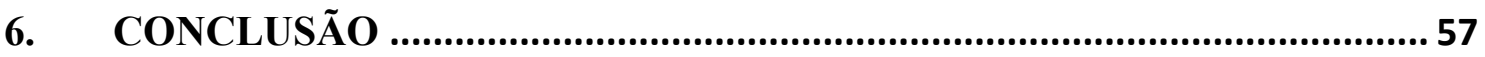

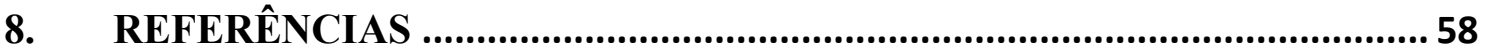




\section{INTRODUÇÃO}

O leite, assim como seus derivados, é considerado um alimento nobre devido ao elevado valor nutricional tanto para crianças quanto para adultos. Ele também apresenta alto valor comercial por ser fonte de renda para os diferentes segmentos da cadeia produtiva do leite (RIBEIRO, 2008; IBGE, 2010; VEIGA et al., 2013). O Guia Alimentar Americano do Departamento de Agricultura dos Estados Unidos (USDA) atribuiu ao leite a característica de ser um alimento de alta qualidade nutricional (USDA, 2010; DREWNOWSKI, 2010). Nesse sentido, a matriz láctea é considerada como constituinte de uma alimentação saudável e, por sua importância, vem buscando novos mercados.

Os búfalos possuem melhor capacidade adaptativa a variações ambientais, além de serem menos susceptíveis à mastite em relação à criação bovina (VIANNI et al., 1999). Além dessa capacidade de resistência a doenças e fatores extrínsecos da criação de búfalas, a matriz láctea bubalina possui maior quantidade de gordura e proteína, o que possibilita a extração de uma diversidade de derivados nutricionalmente mais enriquecidos (SINDHU \& SINGHAL, 1988; ABCB, 2018). As características que favorecem a matriz bubalina são diferentes quando comparadas ao leite bovino, como baixa concentração de colesterol, alto teor de cálcio, magnésio e aminoácidos (CZERWENKA et al., 2010; DALMASSO et al., 2011), altos teores de ácido palmítico e CLA, responsáveis pela atividade antitumorigênica (PALMQUIST, 2001; IP \& PARIZA, 1999) e não possuem em sua composição o $\beta$-caroteno, percussor da vitamina A, o que caracteriza sua coloração esbranquiçada (DUBEY, 1997).

A fim de prevenir alergias e estimular tolerância naqueles que já desenvolvem hipersensibilidade alimentar, a comunidade científica vem buscando novas alternativas no sentido de melhorar a qualidade dos produtos de consumo. Desse modo, a área de lácteos vem expandindo sua pesquisa, pois no leite foram descobertas pequenas moléculas de RNA, chamadas de microRNAs interiorizadas em microvesículas (exossomas) (KOSAKA et al., 2010; BADELLA et al., 2016). Estes pequenos RNAs, com 18-24 nucleotídeos não codificantes estão presentes tanto no interior celular quanto em fluidos biológicos como soro, plasma, urina, saliva e leite (NEGRINI, NICOLOSO \& CALIN, 2009; WEBER. et al., 2010).

MicroRNAs (miRNAs) presentes em leites de vaca e búfala se caracterizam como pequenos RNAs não codificantes que regulam a expressão gênica e controlam diferentes 
processos biológicos e patológicos, tais como desenvolvimento, proliferação, diferenciação e morte celular programada e resposta ao estresse (XIE et al., 2014). Atuam em processos inflamatórios, modulando a inflamação por meio de sua ligação à sequência alvo dos RNAs mensageiros (mRNA), modulando a expressão de citocinas pró e antiinflamatórias (BARTEL, 2009; XU et al., 2011). A alergia à proteína do leite é uma reação imunológica em que o organismo identifica as partículas do leite como sendo um alérgeno, ativando vias de sinalização inflamatórias. Nesse sentido, pode ser interessante a investigação do comportamento miRNAs em relação à hipersensibilidade da proteína do leite, em vista da possibilidade da influência da sua atividade imunomoduladora nas reações inflamatórias (BAZZONI, 2009; ROSSATO, 2012; CURTALE, 2013).

Segundo dados de estudos sobre miRNAs, foram identificados 245 miRNAs no leite bovino (CHEN et al., 2010; IZUMI et al., 2012), sendo que alguns miRNAs, como o miR-29b e miR-200, apresentam sequência homóloga aos miRNAs humanos. O miR29 b aumenta a mineralização óssea em humanos por meio do aumento da diferenciação de osteoblastos com consequente redução na diferenciação de osteoclastos. O miR-200c está relacionado à diminuição do risco de câncer (LEE, 2004; GRIFFITHS-JONES, 2010; ROSSI et al., 2013). Desta forma, quantidades de miRNAs fornecidos pelo leite bovino e absorvidos pelas células humanas poderiam ser suficientes para alterar a expressão do gene humano, ou seja, miRNAs de uma espécie de mamífero podem afetar genes em outra espécie (GRIFFITHS-JONES, 2010; BAIER, 2014). Alguns miRNAs atuam no desenvolvimento morfológico e funcional celular e, atuam como moduladores do sistema imune, por meio da regulação de citocinas (SMYTH et al., 2015), o que os tornam biomarcadores relevantes devido a sua função reguladora na resposta inata e adaptativa (CHO, 2007; ZEN, 2012; SMYTH, 2015).

Além da regulação imune pelos miRNAs, os probióticos garantem o equilibrio da microbiota, condicionando o tipo de resposta imune inata e adaptativa frente a ação de patógenos. A relação microbiota - mucosa intestinal - sistema imune estão intimamente relacionados, na mucosa estão as placas de Peyer e toda extensão de tecido linfóide ligado ao intestino, colaborando no estimulo de células $\mathrm{T}$ e $\mathrm{B}$, produção de $\operatorname{IgA}$ no lúmen intestinal (FULLER, 1997; SALMINEN, 1997). Probióticos são definidos como "microrganismos vivos, que quando administrados em quantidades adequadas, conferem benefícios à saúde do hospedeiro" (FAO/WHO, 2001; Hill e col.; 2014).

Nesse contexto, poucas informações estão descritas na literatura sobre a modificação do perfil de microRNAs em matriz bovina e, principalmente, bubalina 
promovido pelo processo de fermentação com bactérias probióticas, assim como a imunomodulação promovida por microRNAs inter-reinos e a interferência que bactérias probióticas podem exercer. Dessa forma, se faz necessário ampliar os estudos sobre as modificações de miRNAs sofridas na matriz alimentar após o processo de fermentação, bem como seu efeito sobre o hospedeiro. 


\section{EMBASAMENTO TEÓRICO}

O leite, assim como seus derivados, é considerado um alimento nobre devido ao elevado valor nutricional. Sua composição apresenta diversos componentes como vitaminas, minerais, ácidos graxos e proteínas que são responsáveis por este enriquecimento. Devido essa caracterização nutricional, a matriz láctea vem se expandindo no emprego da tecnologia de fermentação com bactérias probióticas. Entre as matrizes que são utilizadas no processo de fermentação destacam-se a matriz bubalina devido algumas características diferenciais em relação a matriz bovina (RIBEIRO, 2008; IBGE 2010; VEIGA et al., 2013).

Durante o processo de fermentação da matriz láctea ocorrem algumas modificações nos componentes presentes como: ácidos graxos e aminoácidos, estes sofrem alterações estruturais que possibilitam o aumento do valor nutritivo das matrizes. Algumas culturas de bactérias probióticas, quando adicionadas a produtos lácteos, possibilitam o aumento de isômeros de CLA por meio da bio-hidrogenação. O CLA é um ácido graxos poli-insaturado que previne processos de carcinogênese e tumorigênese, inibindo o crescimento de tumores e regulando a resposta imune (OLIVEIRA et al 2009; PARIZA et al, 1999). Além de modificações em ácidos graxos, temos a transformação de proteinas em peptídeos bioativos. Os peptídeos bioativos são fragmentos proteicos que apresentam efeitos benéficos na saúde humana, esses são produzidos durante o processo de fermentação pela ação de proteólise dos microrganismos. Esses atuam em processos biológicos de modulação imune, regulação hormonal, atividade antimicrobiana, antioxidante e anti-hipertensiva. Com suas características diversificadas, os torna atrativos para indústria de alimentos e farmacêutica (CHEN, 2010; YOSHIKA, 2003; MOLLER, 2008; AGYEI, 2011)

\subsection{Leite}

Segundo o Regulamento de Inspeção Industrial e Sanitária de Produtos de Origem Animal (RISPOA) “denomina-se leite sem outra especificação, o produto normal, fresco, integral, oriundo de ordenha completa e ininterrupta de vacas sadias, bem alimentadas e descansadas" (IN 31 de 29 de junho de 2018, MAPA).

O leite é composto em média por 3,5\% de gordura, 2,9\% de proteína, 4,3\% de lactose, 8,4\% de sólidos não gordurosos, 12\% de sólidos totais (YE, 2011, BRASIL, 
2013). É um líquido viscoso, obtido pela secreção das glândulas mamárias, constituído de uma fase líquida e partículas em suspensão, formando uma emulsão de óleo em água estável devido a adsorção dos glóbulos de gordura ocorrer entre os vários componentes (SGARBIERI, 2005; BRASIL, 2013).

O leite bubalino apresenta características sensoriais diferentes das do leite bovino, como sabor acentuado característico, mais adocicado e coloração esbranquiçada opaca. Tecnologicamente, sua importância está no processamento de derivados, justificada pela composição físico-química de gordura e micelas de caseína, apresenta maior densidade, acidez, sólidos totais, lactose e minerais (HÜHN et al., 1982) resultando em produtos com bom rendimento. As micelas de caseína do leite bubalino são maiores em relação às do leite bovino, levando a menor retenção de água durante a formação do coágulo do leite (GANGULI, 1979). Verruma e Salgado (1994) identificaram também que leite de búfala apresenta ácidos graxos poliinsaturados em maior proporção que o leite bovino, melhorando o perfil nutricional. Nesse sentido, o leite é uma matriz com alto teor nutritivo que serve de base na regulação de diversas funções fisiológicas do organismo humano (TOMBINI et al., 2012).

O leite humano é a principal fonte alimentar para recém-nascidos, pois proporciona a nutrição necessária para a saúde infantil. O leite materno garante a proteção contra infecções e doenças crônicas, e prepara o intestino por meio da liberação de fatores de crescimento para a ingestão de novos alimentos. Os componentes imunes presentes no leite, como IgA, proporcionam a fórmula certa no combate de agentes patogênicos. Outros componentes imunológicos, como os microRNAs responsáveis pela regulação e diferenciação de células $\mathrm{T}$ e $\mathrm{B}$, foram encontrados nos primeiros 6 meses de lactação. Assim, a alimentação materna e o estilo de vida, estão diretamente relacionados a composição do leite materno, a qual interfere na composição das vesículas extracelulares (PAREDES et al., 2014). Os mircroRNAs encontrados no leite podem ser de origem exossomal ou derivados da dieta materna, portanto as vesículas se formam por dois mecanismos: a partir de um crescente citoplasmático de glóbulos de gordura do leite ou por meio da parte apical de células epiteliais mamárias (IRMAK; OZTAS, 2012; CARVER, 1991; KRAMER, 2001; GOODMAN, 2011; NEWBURG, 2007; HODDINOTT, 2008; TILI, 2008; XIAO, 2009; KRAMER, 2001). 


\subsection{Leite fermentado}

A indústria de laticínios vem ampliando a área de produtos funcionais com destaque para alimentos fermentados. Os produtos fermentados são o resultado da fermentação da matriz alimentar, como por exemplo leite, por bactérias fermentadoras, as quais podem ser ou não probióticas, alterando suas características sensoriais (ORDONEZ et al., 2005; GALLINA et al., 2012). As matrizes de búfala e vaca, quando fermentadas com cultura ácido lática, possibilitam modificações nas características físicoquímicas, sensoriais e perfil de ácidos graxos, que colaboram na formação de um produto final de maior qualidade e aceitabilidade dos consumidores (BORGES, 2009).

Segundo dados da legislação Brasileira, o leite fermentado inclui diversos tipos de produtos, como por exemplo, leite cultivado ou fermentado, kefir, coalhada, iogurte, leite acidófilo; a diferença dentre eles é o tipo de microrganismo usado na inoculação, o tempo de fermentação, as características sensoriais e entre outros fatores das tecnologias empregadas (BRASIL, 2007).

A fermentação do leite consiste na biotransformação do substrato em metabólito, portanto as bactérias ácido láticas transformam o açúcar do leite em ácido lático e ácido acético que aumentam a concentração de $\mathrm{H}^{+}$e diminui o $\mathrm{pH}$ do meio. Durante o processo da fermentação ocorre a modificação de componentes presentes na matriz e a produção de paraprobióticos que são metabólitos produzidos no processo fermentativo (ALMADA et al., 2016). Estes compostos, como peptídeos bioativos e ácidos graxos exercem diversas funções na regulação da homeostasia do organismo (WANG E MEJIA, 2005). Neste contexto, o valor nutritivo atribuído ao produto final é aumentado e a ingestão desse tipo de alimento pode auxiliar no restauro da microbiota intestinal (LIMA 2015; RAMOS 2013). Assim, os probióticos, por meio de competição por nutrientes, produção de compostos bioativos (ácido acético, ácido lático, ácidos graxos de cadeia curta, peptídeos bioativos) e regulação da resposta inata e adaptativa, realizam um remodelamento intestinal tornando o meio desfavorável para microrganismos patogênicos. Dessa forma, impedem a proliferação de patógenos e garantem a homeostasia intestinal (BRIGIDI, 2001; KI CHA, 2012; KAJANDER, 2008; LEROY, 2004).

\subsection{Probióticos}

Probióticos são definidos como "microrganismos vivos, que quando administrados em quantidades adequadas, conferem benefícios à saúde do hospedeiro" 
(FAO/WHO, 2001; Hill e col;; 2014). A conversão luminal de aminoácidos, fibras alimentares, carboidratos dietéticos e vitaminas produzem metabólitos como ácidos graxos de cadeia curta e ramificada ou derivados de aminoácidos como GABA (Ácido gama-aminobutírico) e serotonina. Substâncias como ácido acético, ácido lático, diacetil e peróxido de hidrogênio produzidos durante o processo de fermentação e inibem a atividade de microrganismos patogênicos, tanto por sua ação microbicida quanto por sua ação microstática, equilibrando a microbiota intestinal frente à disbiose (PROTIC et al., 2005; BALLUS et al., 2010). Assim, a matriz láctea fermentada por essas bactérias benéficas pode produzir compostos que enriquecem o leite fermentado e que quando ingeridos, fornecem restauração da mucosa intestinal. Os principais probióticos utilizados na indústria alimentícia pertencem aos gêneros Lactobacillus, Bifididobacterium e Enterococcus faecium (baixas quantidades) devido a identificação em porções saudáveis do intestino como íleo e cólon (CHERBUT, 2003; GOODMAN, 2011; FECHNER, 2014; KASUBUCHI, 2015; BIELECKA et al., 2002). Dentre os microrganismos do gênero Bifidobacterium podemos destacar: B. infantis, B.breve, B. bifidum, B. longum entre outras. No gênero Lactobacillus temos: Lb. casei, Lb. acidophilus, Lb. plantarum, Lb. fermentum e Lb. paracasei (SANDERS, KLAENHAMMER; 2001). As bactérias ácidoláticas são utilizadas industrialmente pois os produtos obtidos durante a fermentação são benéficos à saúde do consumidor e também garantem a conservação do alimento. Além da bactérias benéficas, temos também a levedura Saccharomyces cerivisiae que, além de apresentar aplicação na panificação, vinicultura, produção de destilados, faz-se uso medicinal por ser fonte de vitaminas e proteínas (ROSE, 1997; OMGE, 2008). O Saccharomyces boulardii é usado com finalidade medicamentosa no tratamento de diarréia causada por antibióticos. Assim, cada cepa tem seu mecanismo de ação conforme a finalidade do probiótico aplicado ao produto final (OMGE, 2008).

\section{Mecanismos de ação dos probióticos}

A microbiota quando em disbiose, favorece a colonização por bactérias patogênicas que agridem a mucosa intestinal causando uma série de patologias. Desse modo, os probióticos podem atuar no restauro da microbiota a fim de produzir metabólitos benéficos a saúde (BORCHERS, 2009). Os mecanismos de ação dos probióticos podem ocorrer por diversas vias (Figura 1), incluindo a competição por nutrientes, sítios de adesão, inativação de toxinas, imunomodulação e produção de substâncias 
antimicrobianas (SILVA et al., 2004; MATSUMOTO et al., 2005).

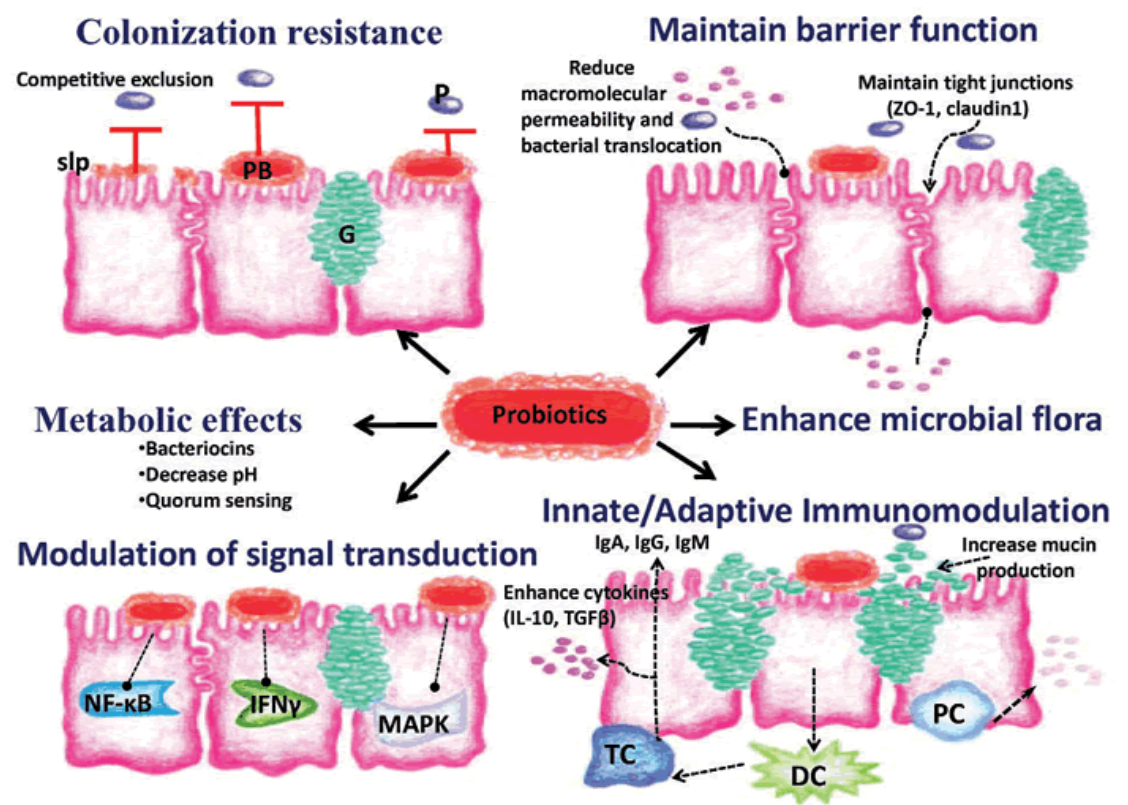

Figura 1 - Mecanismos de ação dos probióticos (Fonte: Nutr Clin Pract. 2009; n24 pg $10-14)$.

\subsection{Bifidobactérias}

As bifidobactérias são bactérias Gram-positivas, não esporuladas, crescem no formato de bastonetes na forma Y, sem motilidade, catalase negativas (MILLER, 2017; WALLER, 2011) termófilas, anaeróbias, heterofermentativas, produzindo ácido lático e ácido acético (GOMES \& MALCATA, 1999), presentes no intestino e fluidos biológicos de humanos e intestino de animais (TURRONI, 2014). Apresentam temperatura de crescimento ideal entre 36 e $40^{\circ} \mathrm{C}$ (GOPAL et al., 2003), devido á essa característica convivem em simbiose com o hospedeiro e são capazes de combater ou controlar microrganismos patogênicos como a Candida albicans e E. coli (LIONG,2004). Nesse sentido, as indústrias de processamento de lácteos têm interesse na utilização dessas bactérias, buscando facilidades de manuseio, processamento e benefícios para consumidores.

Outros estudos mostraram que a imunomodulação causada por bifidobactérias podem contribuir na melhora da resposta imune em doenças inflamatórias como infecções pelo Clostridium difficile, câncer colo retal e a síndrome do colo irritável. Dessa forma, 
podem levar a restauração da microbiota intestinal (PATEL et al., 2014; TOJO et al., 2014).

\subsubsection{Bifidobacterium animalis subsp. lactis HOWARU HN019}

A cepa de Bifidobacterium animalis subsp. lactis HN019 (HN019), foi considerada um probiótico em potencial, baseada em sua capacidade de resistir à bile e a $\mathrm{pH}$ bem ácidos na faixa 4,5 - 5 in vitro (MARCO et al., 2006). Essa cepa mostrou que é capaz de aderir-se em quantidade elevada em diferentes tipos de células de epitélio intestinal como os enterócitos (GOPAL; PRASAD, 2001; HASCHKE, 1998), sendo selecionada devido às suas propriedades imunomoduladoras. Estudos desenvolvidos com um grupo de vinte e cinco adultos saudáveis de meia idade e idosos foram conduzidos durante um período de seis semanas. Sendo 12 idosos (grupo controle), consumiam 180 $\mathrm{mL}$ de leite de baixo teor de lactose e gordura durante duas vezes por semana e 13 idosos (Grupo probiótico) consumiam leite suplementado com Bifidobacterium animalis subsp. lactis duas vezes por semana. Os parâmetros avaliados foram aumento da capacidade fagocitária, produção de interforon e atividade bactericida. Os resultados sugerem que o consumo do leite fermentado durante seis meses de Bifidobacterium animalis subsp. lactis (HN019) aumentou a atividade fagocítica dos monócitos periféricos, sendo capaz de melhorar a resposta-imune inata (GILL; RUTHERFURD et al., 2001, ARUNACHALAM, 1999, ZHOU GILL., 2005). Acredita-se que existam muitos mecanismos pelos quais a HN019 exerce seus efeitos benéficos no Sistema Imune (GOPAL; PRASAD, 2003).

\subsection{Sistema imune de mucosa}

A microbiota intestinal possui uma função fundamental no sistema imunológico e no desenvolvimento de doenças, portanto um desbalanceamento da microbiota intestinal favorece a proliferação de bactérias patogênicas. Muitos fatores influenciam em moldar o estado da microbiota, como a alimentação, a genética e o histórico de doenças (GOODRICH, 2014; LEY, 2005). Nesse sentido, o ecossistema intestinal homeostático garante um organismo saudável, colonizado por bactérias benéficas que produzem metabólitos contribuintes na saúde do hospedeiro. Portanto, o hospedeiro saudável é 
capaz de manter a resposta imune de mucosa contra os antígenos luminais e manter um estado de "inflamação fisiológica" (De LEBLANC et al., 2007).

O funcionamento do sistema imune da mucosa intestinal requer uma complexa rede de sinais com múltiplas interações entre antígenos self e non self e células eucarióticas. Estão inclusas as células epiteliais, macrófagos, células dendríticas e outras células que pertencem à barreira não específica como, por exemplo, as células produtoras de mucina e as células de Paneth, as quais secretam peptídeos antimicrobianos como as criptidinas e defensinas (NEUTRA et al., 2005). As células da mucosa epitelial são cruciais na coordenação destes mecanismos. Elas respondem aos sinais do ambiente pela liberação de citocinas e quimiocinas no recrutamento das células imunes durante as respostas imunes adaptativa e inata. Este recrutamento pode promover a liberação de citocinas pelas próprias células epiteliais, o qual não é desencadeado por bactérias simbiontes patogênicas, controlando a resposta inflamatória (GALDEANO et al., 2007). Esse mecanismo desencadeado pelas bífidobactérias, ocorre devido a constituição das suas paredes celulares, compostas por peptidoglicanos, ácido tecóico e polissacarídeos, responsáveis pela ativação dos macrófagos (COPPOLA \& TURNÊS, 2004; SAAD, 2006; PIMENTEL \& BARBALHO,2007).

\subsection{MicroRNA}

Os miRNAs são pequenos RNAs não codificantes, reguladores póstranscricionais do silenciamento de genes. Portanto, se ligam a sequência alvo dos RNAs mensageiros (mRNA) modulando a inflamação por meio da expressão de citocinas pró e anti-inflamatórias (BARTEL, 2009; XU et al., 2011).

Li e colaboradores (2015) verificaram a expressão gênica de microRNAs presentes na glândula mamária de bovinos lactentes e não lactentes. Identificou-se que 25 miRNAs estavam associados ao desenvolvimento de células epiteliais, desenvolvimento da glândula mamária, regulação da proliferação celular e 38 eram ligados ao metabolismo lipídico e proteína do leite. Isto aponta, que a alimentação dos bovinos pode estar diretamente associada aos produtos do período de lactação, portanto, influenciar na saúde da população que consome essa matriz alimentar (WANG et al, 2016; LI et al, 2015).

A matriz láctea tem alta relevância quando relacionada como regulador epigenético, pois atua no desenvolvimento de genes responsáveis pelo metabolismo celular, influenciando o desenvolvimento de diversas patologias. 


\subsubsection{Formação de microRNA}

A biogênese do miRNA, começa quando o gene é transcrito pela RNA polimerase 2 e gera uma longa cadeia transcrita de RNA primário (pri-miRNA). O pri-miRNA é clivado pela RNASE III, DROSHA, seu cofator DGCR8, gerando uma molécula precursora de RNA madura, chamada de pré microRNA com 70 nucleotídeos. Em seguida o pré-microRNA é exportado pela exportina 5 (proteína de exportação nuclear) para o citoplasma e utiliza o RANGTP como cofator. No citoplasma o pré-microRNA é clivado pelo DICER 1 e junto com a RNA III ocorre o processamento, gerando um microRNA de fita dupla com 22 nucleotídeos. Este produto é incorporado a um complexo multimérico denominado RISC (RNA Induced Silence Complex) que inclui proteínas argonautas. As proteínas argonautas são proteínas catalíticas essenciais no complexo silenciador. Apenas uma das fitas permanece no RISC para controlar a expressão pós transcricional de genes-alvo e a outra sofre degradação. As proteínas argonautas no RISC se ligam ao microRNA indicando a sequência alvo do RNA mensageiro e inibindo a tradução (BERNSTEIN, 2001; SCHWARZ, 2003; LEE, 2003; LEE, 2004; LUND, 2004;).

Os miRNAs são pequenos RNAs não codificantes que podem estar presentes em genes animais e vegetais devido sua produção endógena, sabe-se que um miRNA é capaz de regular 200 RNAs com funções diversas. Considerados como não codificantes pois ligam-se a sequência alvo do RNAm, inibindo o processo de tradução ou degradando o mRNA, portanto são transcritos mas não traduzidos (LEE, 1993). Dessa forma, são chamados de reguladores pós-transcricionais, ao se ligarem ao complexo RISC pelas proteínas argonautas, direcionando a sequência alvo do RNA mensageiro (figura 2). O miRNA pareia de forma complementar ou não complementar ao RNA mensageiro (BRENNECKE, 2005; VALENCIA-SANCHEZ, 2006). 


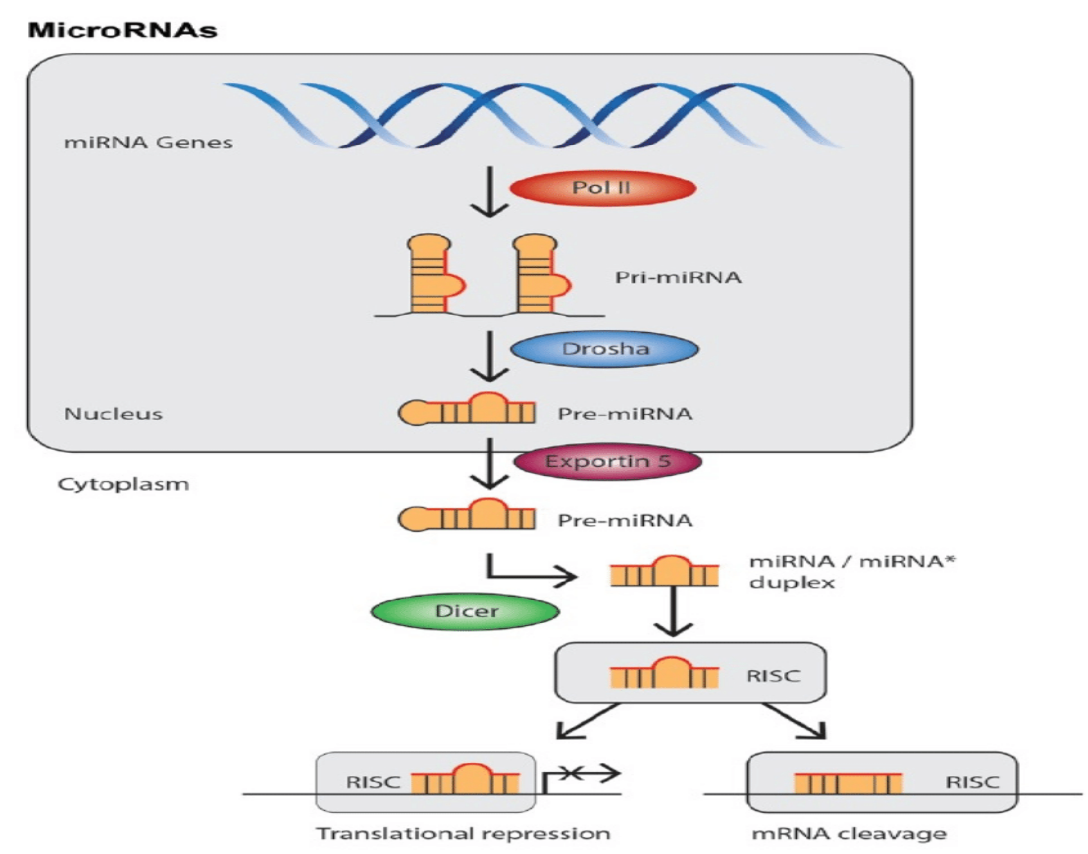

Figura 2 - Biogênese do MicroRNA (Fonte: ZHOU et al., 2014).

\subsubsection{Regulação por microRNAs}

Os microRNAs envoltos por exossomas são absorvidos a partir das matrizes alimentares, como a bovina e bubalina, e podem permear a barreira do intestino por meio de endocitose (IZUMI et al., 2015). Desse modo, os miRNAs imunomoduladores ao se ligarem na sequência alvo do RNA mensageiro das células receptoras podem atuar na diferenciação e desenvolvimento das células B e células T.

Assim, além da função gênica, podem se ligar a receptores TLR (toll-like receptor) e essa interação miRNA-TLR induz a secreção de citocinas inflamatórias (MEDZHITOV, 2000; AKIRA, 2001; LUND, 2004; HEIL, 2004).

\subsubsection{MicroRNAs imunoreguladores}

Os miRNAs imunomoduladores podem ser encontrados com alta homologia entre espécies diferentes. Esta homologia proporciona a capacidade de um miRNA presente em uma matriz alimentar interferir na resposta imune de outra espécie que ingeriu aquele alimento (GUTTMAN, 2012; YOON, 2012), por exemplo, o miRNA- 168 presente em plantas e arroz, apresentou-se em soro de animais e humanos, impactando na diminuição do LDL por meio da ligação LDLRAP1 (Zhang et al. , 2012). Desse modo, os miRNAs 
são capazes de controlar a expressão gênica em espécies diferentes (LAU, 2001; LEE, 2001; GRIFFTHS-JONES, 2004; AMBROS, 2015).

\subsection{Exossomos}

Exossomos são microvesículas microscópicas de 40-100 nm de diâmetro que se formam a partir da liberação das células epiteliais da glândula mamária em diferentes períodos de lactação, sendo responsáveis pela comunicação intercelular (ALSAWEED et al., 2016; DO et al., 2017). A membrana dos exossomos é constituída por lipídos e proteínas. Entre suas funções, destacam-se como veículo para transporte de mRNAs, microRNAs e outros RNAs, como também, na proteção de seu conteúdo interno da degradação pelo meio externo. São vesículas extracelulares responsáveis pela comunicação intercelular por meio da transferência de seus RNAs a células receptoras. Os mecanismos de interação exossoma-célula receptora, consiste nas proteínas transmembranares interagirem com receptores de sinalização da célula alvo ou a fusão dos exossomas (figura 3) à membrana plasmática das células receptoras, entregando seu conteúdo ao citossol ou a internalização das células receptoras (MUNIQUE, 2012; MULCAHY, 2014). Dessa forma, em vista da capacidade dos exossomas de entrega dos ácidos nucleicos e proteínas a longas distâncias torna-os potencias para investigação na terapia gênica e imunológica (RAPOSO et al., 1996; KARLSSON et al., 2001, CLAYTON et al., 2004).

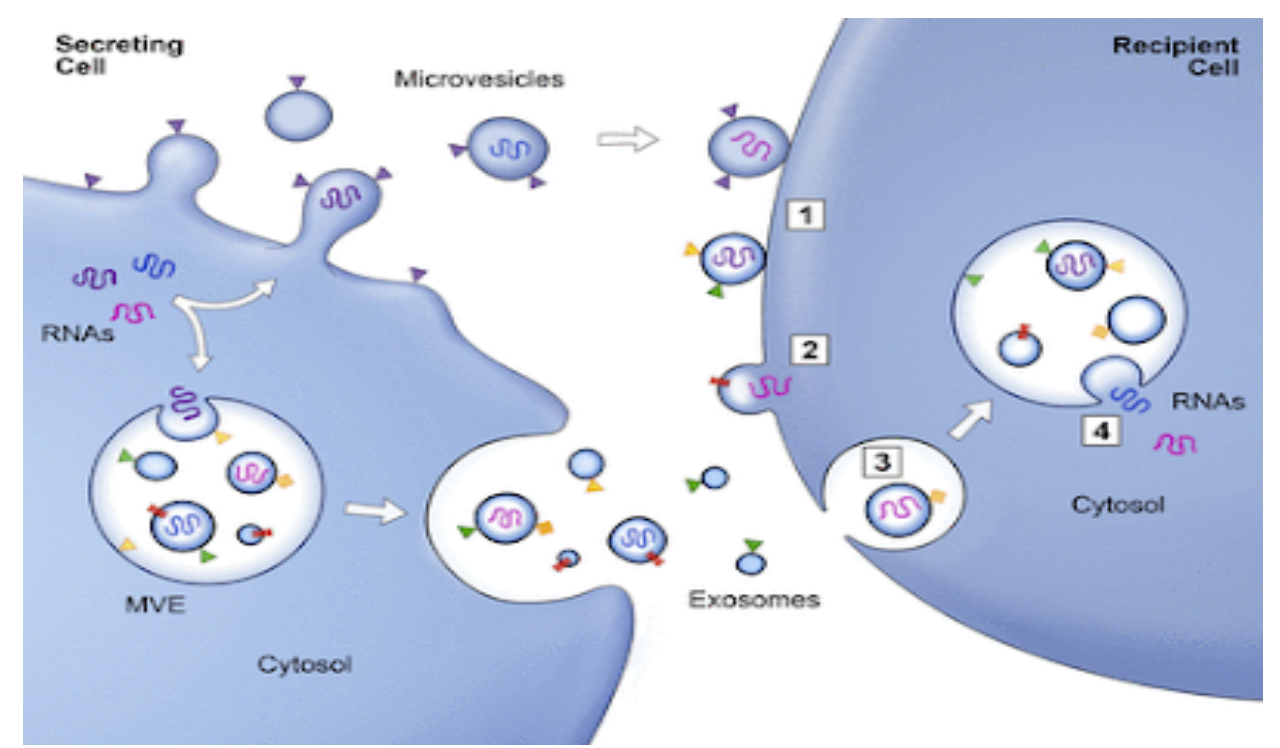

Figura 3 - Mecanismos de ação entre exossoma e célula receptora. Fonte: Raposo; Stoorvogel, 2013. 


\subsection{Xenomirs}

Os Xenomirs são pequenos RNAs não codificantes oriundos da ingestão de alimentos (miRNAs exógenos), sendo capazes de influenciar outros miRNAs. Dessa forma, a relação doença-alimentação está diretamente ligada, pois os alimentos ingeridos provocam alterações na homeostasia do organismo. Portanto, um desbalanceamento da dieta ou uma desregulação metabólica por condições de nutrição como anorexia, bulimia e entre outras, pode ser um fator para levar ao desenvolvimento de doenças avançadas. Nesse sentido, a dieta torna-se um possível fator regulador no desenvolvimento ou regressão de doenças inflamatórias. Segundo um estudo comparativo, avaliou-se dietas vegetarianas e dietas ricas em carne com indivíduos sadios, durante 7 dias. Os resultados obtidos com relação ao miRNA-168 em dietas vegetarianas foram maior do que em dietas ricas em carne, desse modo houve aumento do miRNA-168 advindo de plantas e a possibilidade da influência na mucosa intestinal (JASTIN; 2018).

Nesse contexto, a conservação dos alimentos seja no armazenamento ou no preparo são fatores influentes para absorção destes Xenomirs. Pois dependendo da forma que se prepara o alimento, pode haver a não absorção destes Xenomirs devido a sua degradação pelo tratamento térmico (KENETH et al., 2013).

\subsection{Matriz láctea e microRNA}

As matrizes lácteas bovina e bubalina são matrizes potencialmente nutritivas quando in natura, porém o processo de fermentação com a cepa Bifidobacterium animalis subsp. lactis HN019 (HN019) proporciona maior enriquecimento devido a biotransformação de seus compostos bioativos e alterações nos miRNAs. Desse modo, essas modificações nas matrizes em ácidos graxos e aminoácidos podem ser prejudicadas devido o processamento térmico. Portanto, algumas formas de processamento térmico como tratamento UHT, altera a composição química da matriz em proteínas e carboidratos. A pasteurização por exemplo, inativa micro-organismos patogênicos e enzimas como a fosfatase alcalina e a lactoperoxidase. (CLAEYS; LOEY; HENDRICKX, 2002). Além dos componentes nutricionais os miRNAs presentes podem ser diminuídos devido esse processamento térmico. 


\section{OBJETIVOS}

\subsection{Objetivo geral}

Analisar e comparar a presença de miRNAs imunomoduladores, miR-29b, miR200c, miR-146, miR-155, miR-181a e miR-451, na matriz láctea e bubalina e quanto o processo de fermentação por bactérias probióticas altera este perfil.

\subsection{Objetivos específicos}

(i) Desenvolver os seguintes produtos que sejam estáveis e apresentem contagem adequada de probióticos (isto é $\geq 10^{7} \mathrm{UFC} / \mathrm{mL}$ );

a. Leite bovino integral fermentado por Bifidobacterium animalis subsp. lactis (HOWARU HN019);

b. Leite bubalino integral fermentado por Bifidobacterium animalis subsp. lactis (HOWARU HN019);

(ii) Determinar o efeito imunomodulador de leite fermentado por Bifidobacterium animalis subsp. lactis HOWARU HN019 no intestino de camundongos normais;

(iii) Identificar a presença dos miR-29b, miR-200c, miR-146, miR-155, miR-181a e miR-451 nas matrizes láctea e bubalina antes e após a fermentação por Bifidobacterium animalis subsp. lactis HOWARU HN019. 


\section{MATERIAL E MÉTODOS}

\section{Procedimento experimental - Parte I}

\subsection{Preparo do inóculo}

Para o preparo do inóculo, foi utilizad 0,9g de cultura probiótica comercial B. animalis subsp. lactis HOWARU HN019 (Dupont, São Paulo) em 100 mL de leite desnatado esterilizado (Molico, Nestlé, São Paulo) conforme padronizado por Florence e colaboradores (2014). A cultura foi hidratada em banho maria a $37^{\circ} \mathrm{C}$ durante 15 minutos. Essa hidratação em banho maria favorece o crescimento da cepa probiótica e contribui para a obtenção da contagem do inóculo superior ou igual a $10^{7} \mathrm{UFC} / \mathrm{mL}$ durante o processo de fermentação.

\subsection{Fermentação}

Os leites, tanto o adquirido no mercado (bovino) quanto o recebido da fazenda (bubalino) foram pasteurizados a $65^{\circ} \mathrm{C}$ por 30 minutos, 24 horas antes da fermentação. Ao leite pasteurizado, foi inoculado $1 \mathrm{~mL}$ de inóculo para cada $500 \mathrm{~mL}$ de matriz láctea e homogeneizado por $1 \mathrm{~min}$. Após a homogeneização a fermentação foi realizada em banho maria a $37^{\circ} \mathrm{C}$ e monitorada pelo sistema CINAC (Ysebaert, Frepillon, Franca), isto é, mediante um método automático para a quantificação da atividade de uma cultura probiótica com base em medidas de valores de pH (SPINNLER \& CORRIEU, 1989) até atingir pH 4,5. Após este período, a fermentação foi interrompida e o leite fermentado resfriado até $10^{\circ} \mathrm{C}$ em banho de gelo, o coagulo foi quebrado por agitação mecânica com bastão de inox por 1 min e armazenado sob refrigeração a $4 \mathrm{oC}$ até a análise. Os experimentos foram feitos em duplicata. A partir dos dados obtidos, foi calculada a velocidade máxima de acidificação $(\mathrm{d} p H / \mathrm{dt})$ expressa como miliunidades de $\mathrm{pH} / \mathrm{min}$ $(V \max )$. No final do período de incubação foram ainda calculados os seguintes parâmetros cinéticos: $t_{v \max }$ (tempo no qual se atinge a velocidade máxima em $\mathrm{h}$ ) e $t_{f}$ (tempo de fermentação ou tempo para atingir valor de $\mathrm{pH}$ 4,5 em h). 


\subsection{Acondicionamento e armazenamento}

Os leites fermentados de búfala e vaca foram transferidos manualmente para potes de plásticos de $50 \mathrm{~mL}$ e identificados de modo que pudessem ser analisados imediatamente após a fermentação e 1, 7, 14 e 21 dias após a fermentação, mantidos sob refrigeração a $4^{\circ} \mathrm{C}$.

\subsection{Análises físico-químicas}

As seguintes análises físico-químicas foram realizadas a fim de avaliar a composição do leite fermentado: sólidos totais, proteína, $\mathrm{pH}$ e densidade. Todas as análises foram conduzidas em aparelho digital Ekomilk (EON Trading \& Bulteh 2000, Stara Zagora, Bulgaria) e metodologia clássica comparativa preconizada pelo Instituto Adolfo Lutz (BRASIL, 1981).

As medidas dos valores de $\mathrm{pH}$ foram realizadas em potenciômetro digital (Kasvi, São Paulo).

\subsection{Enumeração}

Para a enumeração das bifidobactérias, foi diluido $1 \mathrm{~mL}$ do leite fermentado em 9 $\mathrm{mL}$ de água peptonada, homogeneizada e realizada a diluição seriada utilizando-se o mesmo diluente e, $1000 \mu \mathrm{L}$ da diluição apropriada foi inoculada em meio seletivo. A cultura comercial de B. animalis subsp. lactis foi enumerada no meio seletivo RCA Agar com adição de azul de anilina $(0,03 \%)$ e $100 \mu \mathrm{L}$ do antibiótico Dicloxacilina para cada $100 \mathrm{~mL}$, após incubação a $37^{\circ} \mathrm{C}$ por 72 horas em jarra de anaerobiose e AnaeroGen (Oxoid, Basingstoke). Placas contendo de 20 a 200 colônias foram enumeradas e as unidades formadoras de colônias por grama de produto (UFC/g) foram calculadas (SACARO et al., 2011).

\subsection{Extração de exossomos}

Dez (10) $\mathrm{mL}$ de leite bovino e bubalino foram centrifugados em tubo cônico de $50 \mathrm{~mL}$ (Falcon, USA) a 5000g em centrifuga refrigerada (Hermle Labor Technic, Wehingen, Alemanhã) a $4^{\circ} \mathrm{C}$ por 30 minutos, seguido de nova centrifugação a $10000 \mathrm{~g}$ 
por 30 minutos para realizar o desnate do leite.

Ao sobrenadante foi adicionado $4 \mathrm{~mL}$ de solução padrão B (kit MIRCURY ${ }^{\mathrm{TM}}$ Exosome Isolation Kit, Exiqon, Woburn, USA) e incubado a $4^{\circ} \mathrm{C}$ overnight. Após esse período, a amostra foi centrifugada a $3200 \mathrm{~g}$ durante 30 minutos a temperatura ambiente e o pellet recolhido, conforme instruções do fabricante.

\subsection{Análise dos microRNAs}

Após isolar os exossomas, foram investigados os miR-29b, miR-200c, miR-146, miR-155, miR-181a e miR-451. Após a extração descrita no item 4.6, as amostras de miRNAs foram convertidas em cDNA através da reação de transcrição reversa utilizando o kit TaqMan ${ }^{\circledR}$ MicroRNA Reverse Transcription (Applied Biosystems, EUA) combinado com os oligonucletídeos específicos para os miRNAs alvos providos pelo kit TaqMan ${ }^{\circledR}$ MicroRNA Assays (Applied Biosystems, EUA) de acordo com o protocolo descrito pelo fabricante. A quantificação relativa da expressão de cada miRNA foi mensurada por meio da técnica de reação em cadeia da polimerase em tempo real quantitativo (qRT-PCR) utilizando-se o kit TaqMan® MicroRNA Assays com sondas específicas para cada miRNA estudado. As reações foram realizadas em duplicata, por meio do kit TaqMan® Universal PCR Master Mix, No AmpErase ${ }^{\circledR}$ UNG (Applied Biosystems, EUA), na plataforma Step One Plus ${ }^{\mathrm{TM}}$ Real-Time PCR Systems (Applied Biosystems, EUA). 
Procedimento Experimental - Parte II

\subsection{Desenho experimental}

A dieta e os experimentos realizados seguiram o seguinte desenho (figura 4).

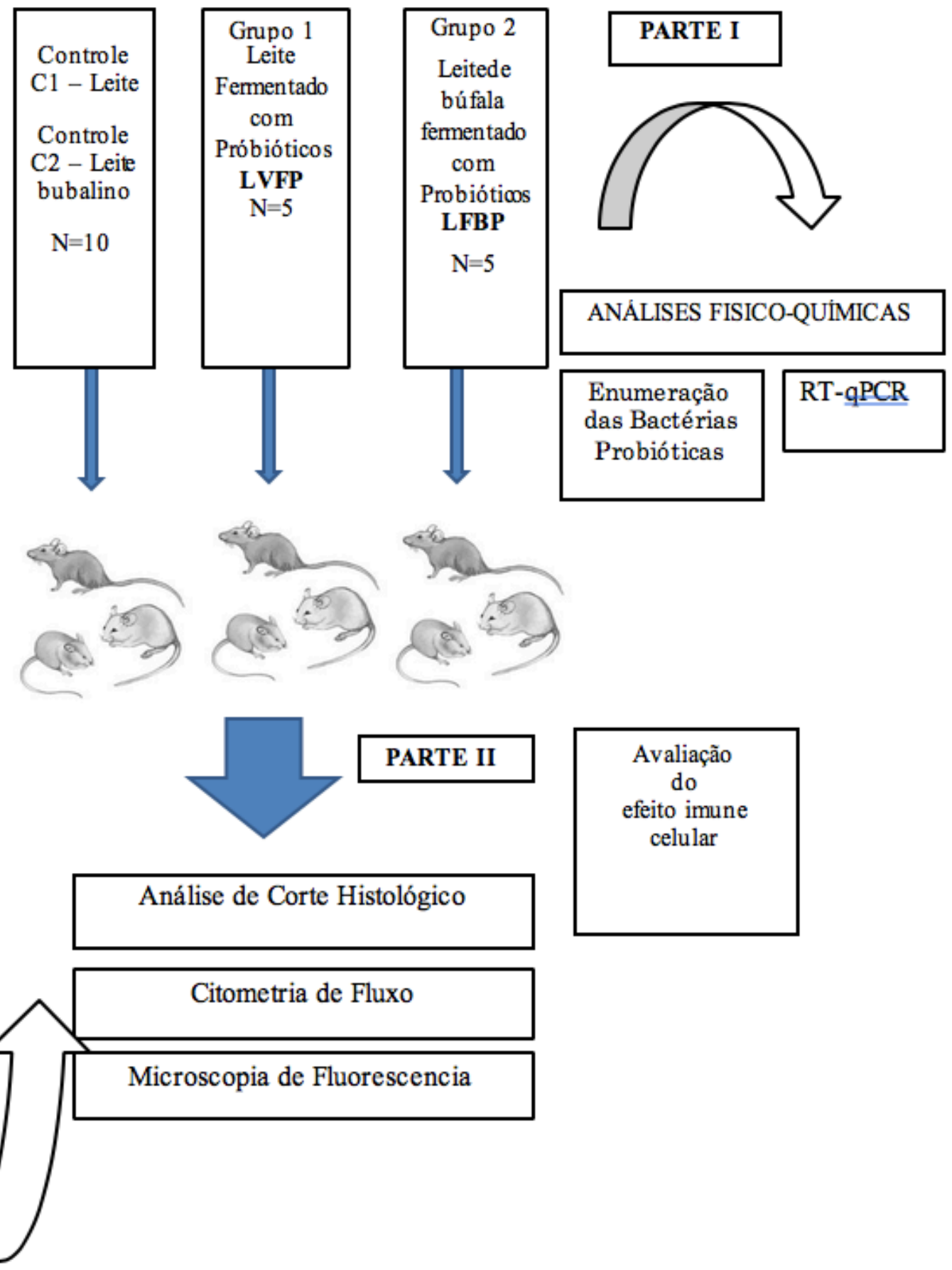

Figura 4 - Desenho experimental. 


\subsection{Animais e Dietas}

Foram utilizados camundongos isogênicos da linhagem BALB/c, machos, com idade de 21 dias e $20 \mathrm{~g}$ de peso corporal inicial, distribuídos ao acaso em cada um dos seguintes grupos experimentais $(n=40)$ :

Grupo 1: $\quad$ Controle C1 (Leite integral bovino);

Grupo 2: $\quad$ Controle C2 (Leite integral bubalino);

Grupo 3: $\quad$ Leite bovino fermentado com B. animalis subsp. lactis HOWARU HN019; Grupo 4: $\quad$ Leite bubalino fermentado com B. animalis subsp. lactis HOWARU HN019.

Estes animais foram colocados em gaiolas $(n=5)$ em biotério a temperatura ambiente $\left(22 \pm 2^{\circ} \mathrm{C}\right)$ com umidade constante e foto-período controlado de $12 \mathrm{~h}$ de luz e $12 \mathrm{~h}$ de escuro. Os animais receberam ração comercial e os produtos lácteos em estudo, administrados aos grupos diariamente ad libitum. O peso corporal dos animais foi registrado diariamente, exceto aos finais de semana. Ao término do período experimental os animais foram eutanasiados por sobredosagem de quetamina $(300 \mathrm{mg} / \mathrm{kg})$ associado à xilazina $(30 \mathrm{mg} / \mathrm{kg})$, por via intraperitoneal. (figura 4$)$.

\subsection{Análise do infiltrado linfocitário por corte histológico}

Após a eutanásia dos camundongos uma pequena porção do colón ascendente e descendente foram recolhidas e fixadas em formalina a $4 \%$ durante $24 \mathrm{~h}$. O material foi encaminhado a empresa Histotech para a continuação da desidratação, inclusão em parafina e cortes de aproximadamente $5 \mathrm{~mm}$. Parte do material foi corado por hematoxilaeosina e azul oceano e parte dos cortes foram incluídos em lâminas cilanizadas para marcação de imunofluorescência e posterior análise em microscopia de fluorescencia. 


\subsection{Análise da modulação imunológica celular no cólon por técnica de Imunofluorescência}

Os cortes foram reidratados em bateria de xilol e álcool, foi realizada a ativação antigênica por aquecimento por $10 \mathrm{~min}$ em micro-ondas, resfriados e colocados em câmara úmida, foram incubados com anticorpos marcadores afim de localizar os seguintes tipos celulares: (i) células B - marcador de receptor de superfície IgA e IgM (ii) Macrófagos marcador de receptor de superfície CD11b. Foram usados como marcadores anticorpos de camundongo, feitos em rato e conjugados com isoticianato de fluoresceína (FITC), R-ficoeritrina (R-PE) e (Cy-5) de acordo com a necessidade de cada grupo. Após diluição, seguiu incubação por uma hora à temperatura ambiente, abrigada da luz. Após este período, os cortes foram lavados quatro vezes em PBS e observados e quantificados em microscópio de Fluorescência (BOGSAN et al., 2014).

\subsection{Análise da modulação imunológica celular no intestino delgado por técnica de citometria de fluxo.}

Após eutanásia dos animais, o intestino delgado foi submetido à digestão por colagenase para soltura das células. Após a digestão as células foram lavadas com solução de PBS e acondicionadas em tubos eppendorf plásticos de 1,5 $\mathrm{mL}$ em banho de gelo. As suspensões celulares foram divididas em grupos, centrifugadas por 4 min a 500 RPM e suspensas em solução de PBS contendo os anticorpos específicos para cada grupo. Estes grupos foram compostos de forma a identificar os seguintes tipos celulares: (i) células B1a -marcadores de receptor de superfície CD11b+, IgM ${ }^{\text {high }}$, IgD ${ }^{\text {low }}$ e CD5+ ; (ii) células B-1b - marcadores de receptor de superfície CD11b+, IgM ${ }^{\text {high }}$, IgD low e CD5-; (iii) células B-2 - marcadores de receptor de superfície CD11b-, IgM ${ }^{\text {low }}$ IgD $^{\text {high }}$ e CD5-; (iv) células T helper - marcadores de receptor de superfície CD3+, CD4+; (v) células TCD8+ marcadores de receptor de superfície CD3+, CD8+. Foram usados como marcadores os anticorpos de camundongos, feitos em rato e conjugados com isoticianato de (FITC), Rficoeritrina (R-PE) e (Cy-5) de acordo com a necessidade de cada grupo. Após diluição, foi feita a incubação dos anticorpos no período de uma hora em banho de gelo. As células foram lavadas três vezes em solução de PBS e analisadas por citometria de fluxo em aparelho FACScanto no Departamento de Análises Clinicas da Faculdade de Ciências Farmacêuticas - USP. 


\section{RESULTADOS E DISCUSSÃO}

\section{Execução Experimental - Parte I}

\subsection{Comparação físico química das matrizes bovina e bubalina}

Foi comparado o perfil físico-químico a fim de avaliar a composição do leite fermentado de vaca e búfala, assim como seus controles de vaca e búfala sem fermentações. Nestes quesitos, avaliou-se: sólidos totais, proteína, $\mathrm{pH}$ e densidade. Todas as análises foram conduzidas em triplicata em aparelho digital Ekomilk®, EON Trading \& Bulteh 2000 (Stara Zagora, Bulgária) e pelo método clássico preconizado pelo Instituto Adolfo Lutz (Brasil, 1998). As medidas dos valores de $\mathrm{pH}$ foram realizadas em potenciômetro digital (KASVI, São Paulo).

Ao compararmos as duas metodologias ekomilk e clássica, não houve diferença estatisticamente significante, sendo validada a metodologia ekomilk para matriz láctea bubalina (figura 5). Ao analisarmos a proporção de gordura, sólidos totais não gordurosos e proteínas observamos que a matriz bubalina apresenta quantidade maior em relação a matriz bovina conforme descrito abaixo.

\section{Comparação das metodologias Ekomilk e Instituto Adolfo Lutz}

Análises tradicionais preconizadas pelo Instituto Adolfo Lutz (1995) foram realizadas para sólidos totais não gordurosos, gordura e proteína em matrizes láctea e bubalina, e leites fermentados probióticos (Figura 5). Foram realizadas análises: fórmula de Fleischmann (PREGNOLATTO e PREGNOLATTO, 1985) em conjunto com dados de densidades das matrizes fornecidos pelo Ekomilk ${ }^{\circledR}$ para sólidos totais não gordurosos, nitrogênio total (BRASIL, 1981a) para determinar proteínas, Butirométrico para leite fluído para lipídios (BRASIL, 1981b). 

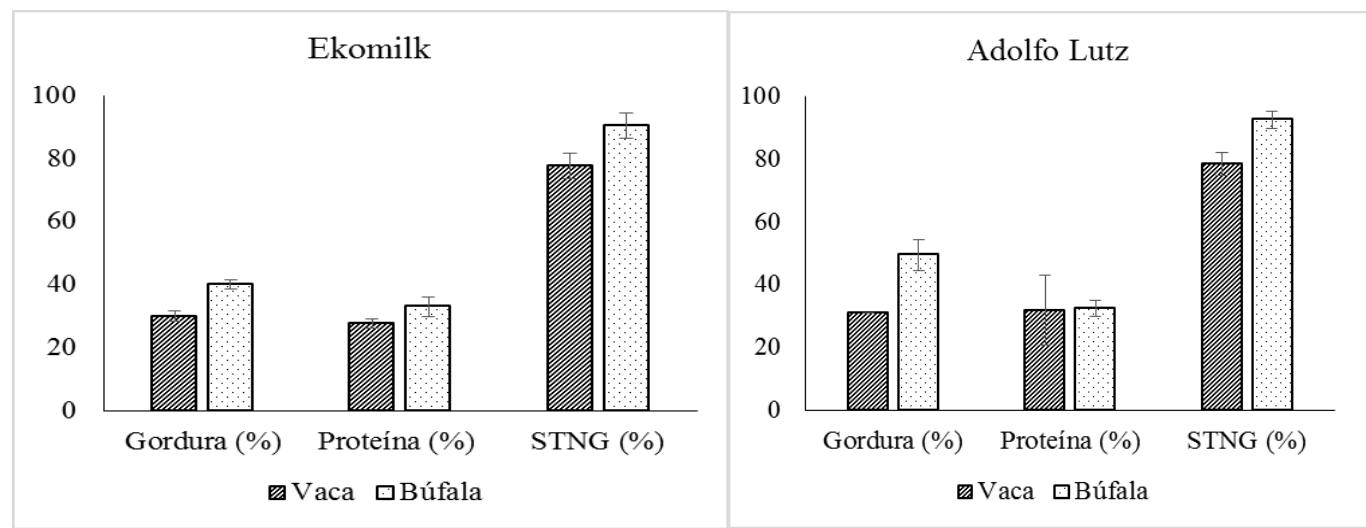

Figura 5- Comparação da metodologia Ekomilk e Adolfo Lutz nas matrizes lácteas bovina e bubalina $(\mathrm{P}<0,05)$.

\subsection{Desenvolvimento dos produtos lácteos - cinética de acidificação}

A fermentação por HN019 teve início com diferença de pH entre os leites, sendo pH 6,6 para a matriz bovina e $\mathrm{pH}$ 6,5 para matriz bubalina. A fermentação foi interrompida em pH 4,7 após 16,60 h de fermentação para a matriz bovina e 20,80 h para matriz bovina (Figura 6). Apesar do tempo para chegar em $\mathrm{pH} \mathrm{4,7} \mathrm{ser} \mathrm{maior} \mathrm{na} \mathrm{matriz}$ bubalina, os tempos para atingir Vmax, TpH5,5, tpH 5,0 e os demais parâmetros cinéticos foram alcançados antes. Estes dados indicam que tecnologicamente a matriz bubalina apresenta vantagens no desenvolvimento de leites fermentados (tabela 1).

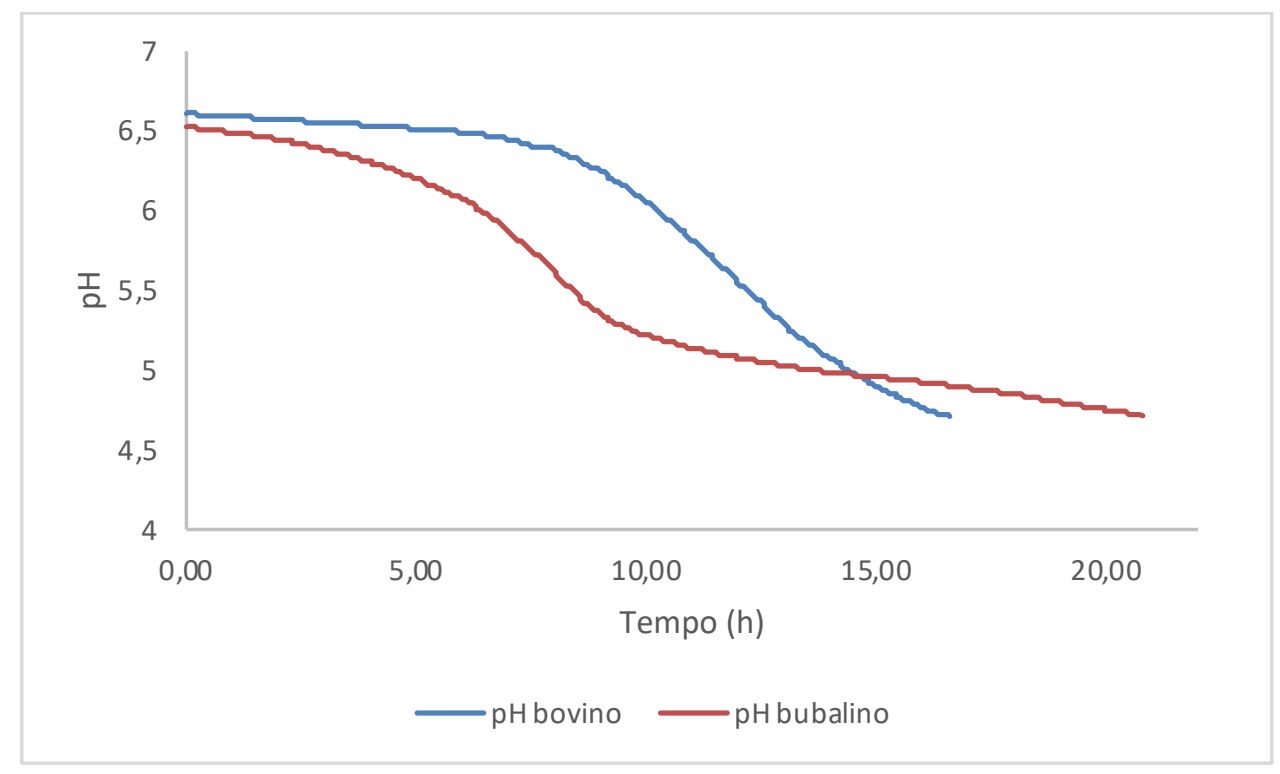

Figura 6 - Curva de acidificação da fermentação por HN019 em matriz bovina e bubalina. 
Tabela 1 - Parâmetros cinéticos da fermentação de matriz láctea bubalina e bovina por cultura de HN019.

\begin{tabular}{lcccccc}
\hline Matriz & $\begin{array}{c}\mathrm{pH} \\
\text { inicial }\end{array}$ & $\begin{array}{c}\text { Tmax } \\
(\mathrm{h})\end{array}$ & $\begin{array}{c}\mathrm{pH} \mathrm{em} \\
\mathrm{Vmax}\end{array}$ & $\begin{array}{c}\mathrm{tpH} 5,5 \\
(\mathrm{~h})\end{array}$ & $\begin{array}{c}\mathrm{tpH}, 0 \\
(\mathrm{~h})\end{array}$ & $\begin{array}{c}\mathrm{tpH} 4,7 \\
(\mathrm{~h})\end{array}$ \\
\hline Bovina & 6,60 & 12,67 & 5,41 & 12,33 & 14,53 & 16,60 \\
Bubalina & 6,53 & 8,20 & 5,60 & 8,53 & 13,73 & 20,80 \\
\hline
\end{tabular}

Análise de $\mathrm{pH}$

A pós acidificação da matriz bubalina é menor do que a apresentada pela matriz láctea bovina até o sétimo dia de refrigeração, no entanto, a partir do 14 dia de refrigeração as ambas as matrizes se igualam no perfil de pós acidificação (figura 7).

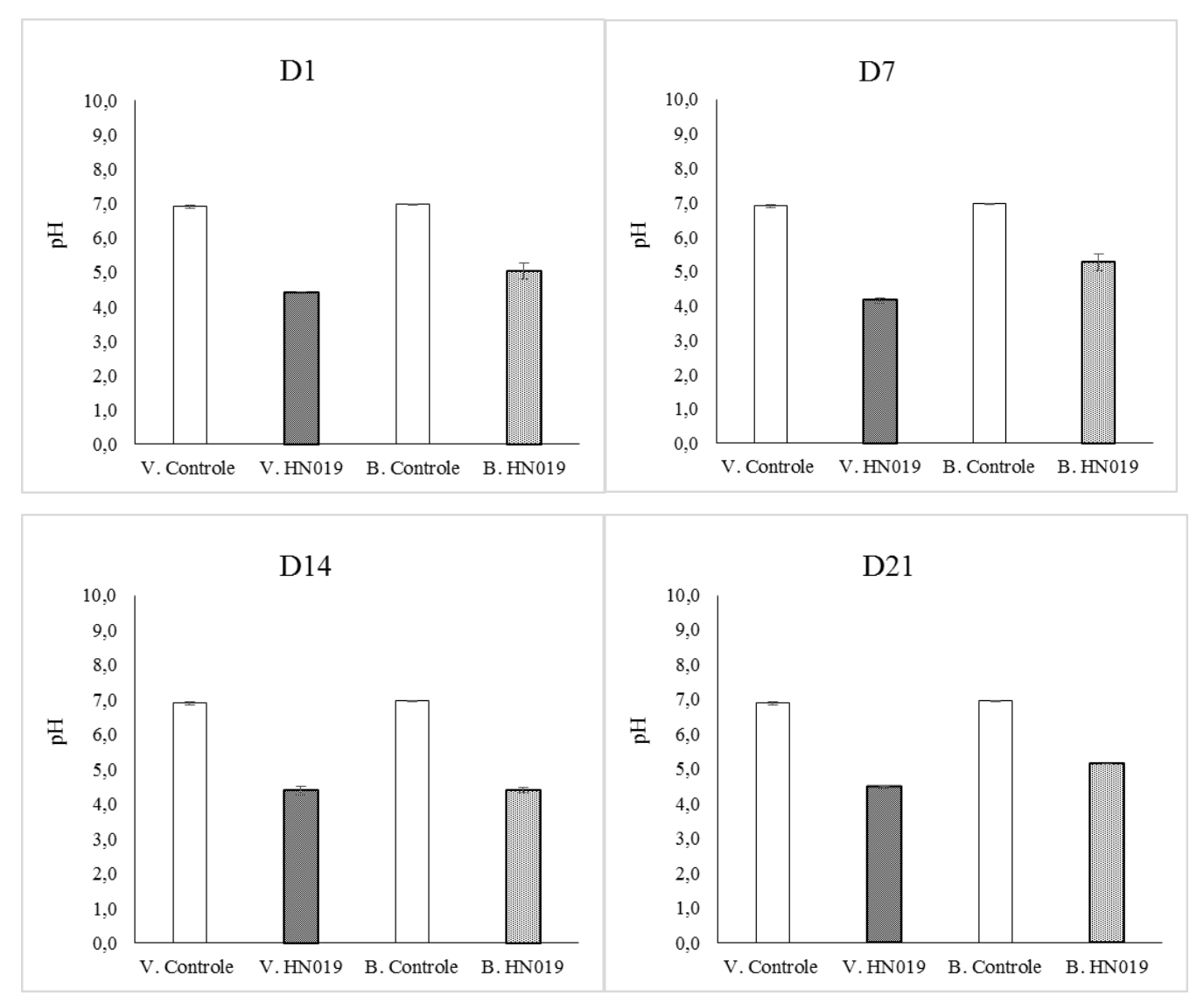

Figura 7- Análise de pH dos leites fermentados nos dias 1, 7, 14 e 21 após a fermentação sob armazenamento a $4^{\circ} \mathrm{C}(\mathrm{P}<0,5)$. 


\subsection{Desenvolvimento dos produtos lácteos - análises microbiológicas}

Foi analisada a viabilidade das bactérias Bifidobacterium animalis subsp. lactis HN019 fermentada em matriz bubalina e bovina pelo período de 21 dias de vida de prateleira. Observou-se que um dia após a fermentação (D1) houve diferença estatística entre matriz bovina e bubalina, porém não significante. Ao comparar a viabilidade 14 dias após a fermentação (D14), foi notado que a matriz bubalina apresentou-se com maior viabilidade de bactérias em relação a matriz bovina, enquanto que 21 dias após a fermentação a matriz bovina apresentou pequena diferença em relação a matriz bubalina (figura 8).

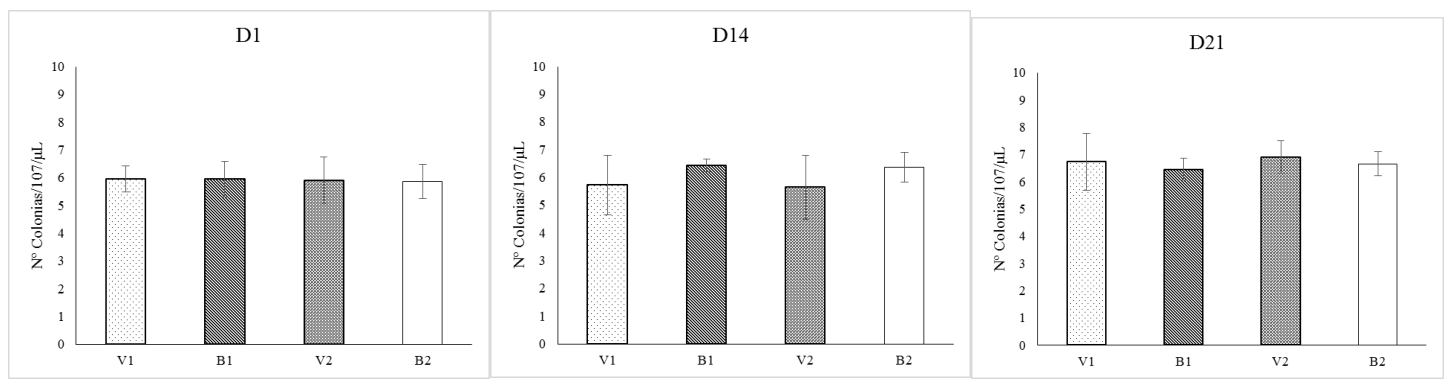

Figura 8- Viabilidade da bactéria HN019 nas matrizes bovina e bubalina nos dias 1, 14 e 21 de armazenamento sob refrigeração a $4^{\circ} \mathrm{C}(\mathrm{P}<0,5)$.

\subsection{Desenvolvimento de produtos lácteos - extração de exossomos}

Após o desnate das amostras de leites bovino e bubalino, foi realizada a precipitação dos exossomos para posterior extração, segundo normas do fabricante (kit MIRCURY ${ }^{\mathrm{TM}}$ Exosome Isolation Kit, Exiqon, Woburn, USA). Após o período de overnight das amostras, realizou-se a centrifugação por 30 minutos a $3200 \mathrm{rpm}$ a $20^{\circ} \mathrm{C} . \mathrm{O}$ sobrenadante foi descartado e ao pellet foi adicionado $350 \mu \mathrm{L}$ da solução tampão de lise aos pellets do leite e leite bubalino. Após homogeneizar por $15 \mathrm{seg}$, foi adicionado 200 $\mu \mathrm{L}$ de etanol $100 \%$ às amostras de leite e leite de búfala para a extração dos exossomas conforme informações do fabricante. 


\subsection{Análise da expressão de miRNAs por PCR quantitativa em tempo real (RT-qPCR)}

A extração de miRNAs foi realizada através do kit MiRNeasySerum/Plasma (Qiagen, EUA) de acordo com o protocolo descrito pelo fabricante. Os miRNAs analisados foram os miR-29b, miR-200c, miR-146, miR-155, miR-181a e miR-451.

A quantificação relativa da expressão de cada miRNA foi mensurada por meio da técnica de reação em cadeia da polimerase em tempo real quantitativo (qRT-PCR) utilizando-se o kit TaqMan ${ }^{\circledR}$ MicroRNAAssays com sondas específicas para cada miRNA a ser estudado.

\section{Extração de miRNA e síntese de cDNA}

RNA total, incluindo miRNAs, foi extraído do pellet de exossomos usando o miRCURY RNA Isolation Kit (Exiqon, Woburn, MA, EUA), seguindo recomendações do fabricante. O RNA total foi convertido em cDNA pela reação de transcrição reversa usando o Universal cDNA Synthesis Kit II (Exiqon, Woburn, MA, EUA) em termociclador Veriti ${ }^{\mathrm{TM}}$ 96-Well (Applied Biosystems, Carlsbad, CA, EUA). Um controle exógeno (Spike-in control miR-39) foi adicionado a reação. Os cDNAs sintetizados foram armazenados a $-20^{\circ} \mathrm{C}$ até a realização da PCR em tempo real.

\section{Expressão de miRNA pela $R T-q P C R$}

Para a realização dos estudos da PCR em tempo real foram utilizados os ensaios pré-validados do fabricante Exiqon dos seguintes miRNAs: rno-miR-146b-5p, gga-miR451, hsa-miR-29b-3p, hsa-miR-200c-3p, hsa-miR-155-5p, ssc-miR-181a. A amplificação foi realizada no sistema automatizado ABI 7500 Fast (Applied Biosystems, Carlsbad, CA, EUA) utilizando o ExiLENT SYBR Green master mix (Exiqon, Woburn, MA, EUA).

Os miRNAs não foram identificados após o protocolo realizado, porém o miRNA39, utilizado no controle de qualidade, foi amplificado nos controles de vaca e búfala e em ambas as matrizes fermentadas. Desse modo, alguns fatores podem ser influentes nesse resultado final pois houve amplificação apesar da não identificação dos miRNAs do processo final. Nesse sentido, segundo dados de literatura, a lactação das vacas e búfalas tem diferentes períodos, sendo seus níveis de miRNAs variantes na matriz crua em relação as matrizes processadas (XI CHEN, 2010). Em outros estudos, percebeu- 
se que o leite pasteurizado em relação ao leite cru apresentava uma porcentagem de miRNA menor comparado a matriz pasteurizada e essa diferença também foi constada na fórmula infantil em relação ao leite materno (KIRCHNER, 2016; MUTIUS, 2012). Ainda foi relatado que, o processo de fermentação é capaz de degradar os exossomas responsáveis pelo microencapsulamento dos miRNAs. Isso é possível, pois os microorganismo liberam proteases que degradam as membranas dos exossomas e dessa forma, os miRNAs são liberados no meio e então degradados (EITAN,2015; SIRUN, 2017).

Desta forma, se faz necessário modificar a técnica de estudo e realizar um screening dos miRNAs presentes no leite antes e após o processo de fermentação. Por esta avaliação, podemos dizer que tanto o processo de pasteurização quanto o processo de fermentação degradam os miR-29b, miR-200c, miR-146, miR-155, miR-181a e miR451, não sendo estes responsáveis pela imunomodulação encontrada nos animais após o consumo dos leites fermentados.

\subsection{Análise histológica do infiltrado linfocitário por HE e do muco por Azul Oceano do cólon de camundongos.}

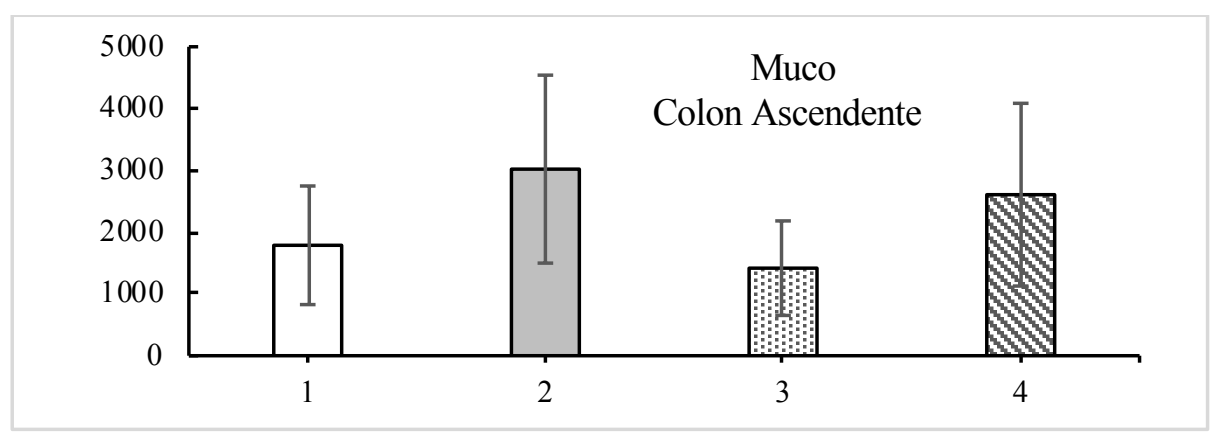

Figura 9 - Microscopia Óptica de muco cólon ascendente, grupo 1 - leite, grupo 2 - leite fermentado, grupo 3 - leite bubalino e grupo 4 - leite bubalino fermentado $(\mathrm{P}<0,05)$.

Ao ser avaliada a quantidade de muco no cólon ascendente comparando a matriz láctea bovina (grupo 1) com a matriz bovina fermentada (grupo 3), foi notada uma redução de muco no grupo 3 que recebeu a matriz fermentada em relação ao grupo 1 . Enquanto que no cólon ascendente a matriz láctea de búfala (grupo 2) em relação a búfala fermentada (grupop 4) houve redução de muco. O leite de búfala produziu mais muco do que o leite tanto pasteurizado quanto fermentado por HN019 (Fig. 9 e 10). 

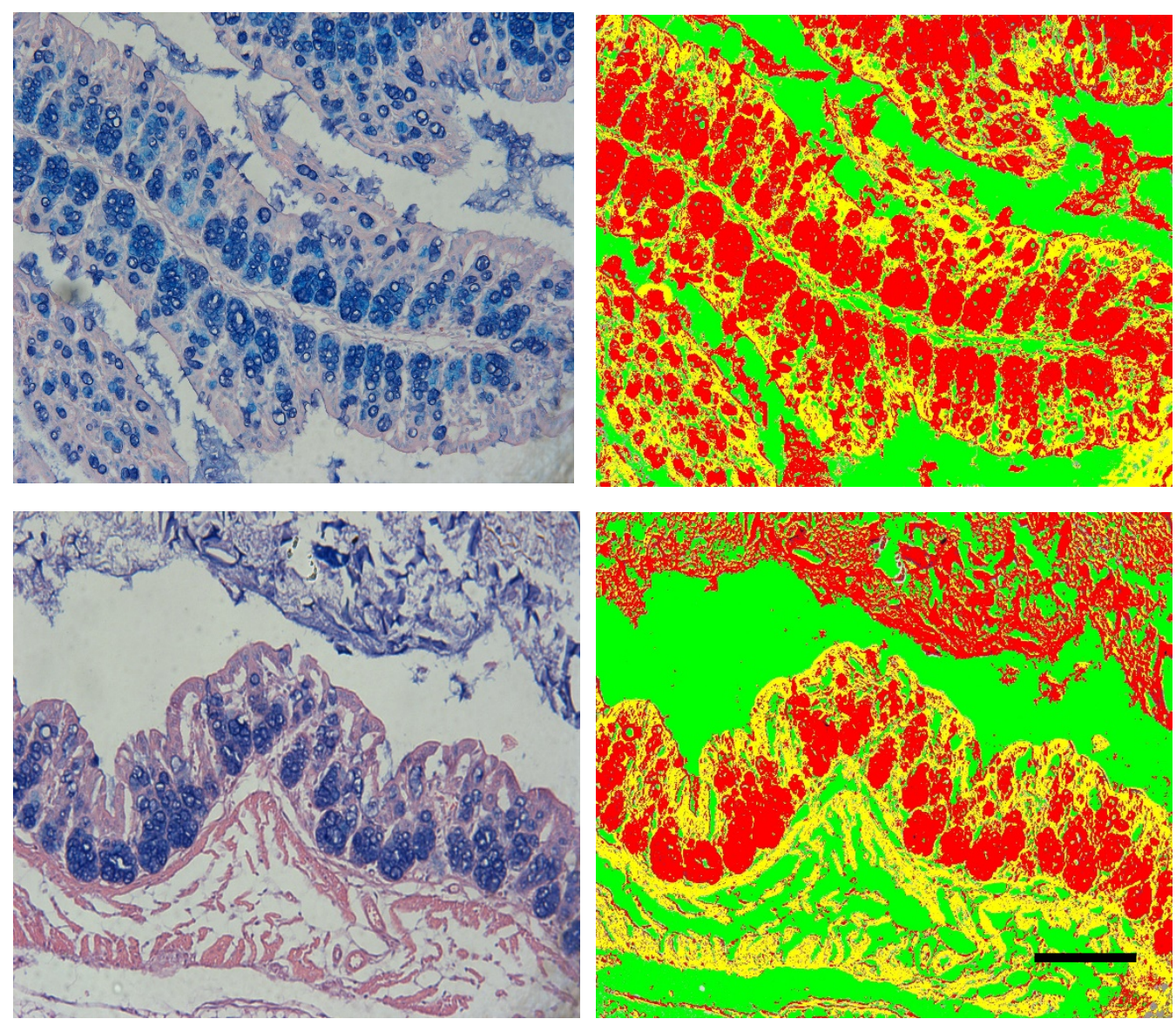

Figura 10. Histologia de colón ascendente de animais que consumiram leite por 14 dias, coradas com azul oceano (A - bovino e C - bubalino) mostrando produção de muco e contraste para quantificar em porcentagem as porções de muco em vermelho, mucosa em amarelo e luz em verde (B - bovino e D - bubalino).

Ao contrário do cólon ascendente, no cólon descendente não há diferença significativa entre a produção de muco pelo consumo de matriz láctea bovina pasteurizada ou fermentada. Entretanto, a matriz láctea de búfala pasteurizada gera menor produção de muco em relação a fermentada (figura. 11 e 12).

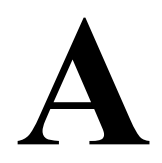




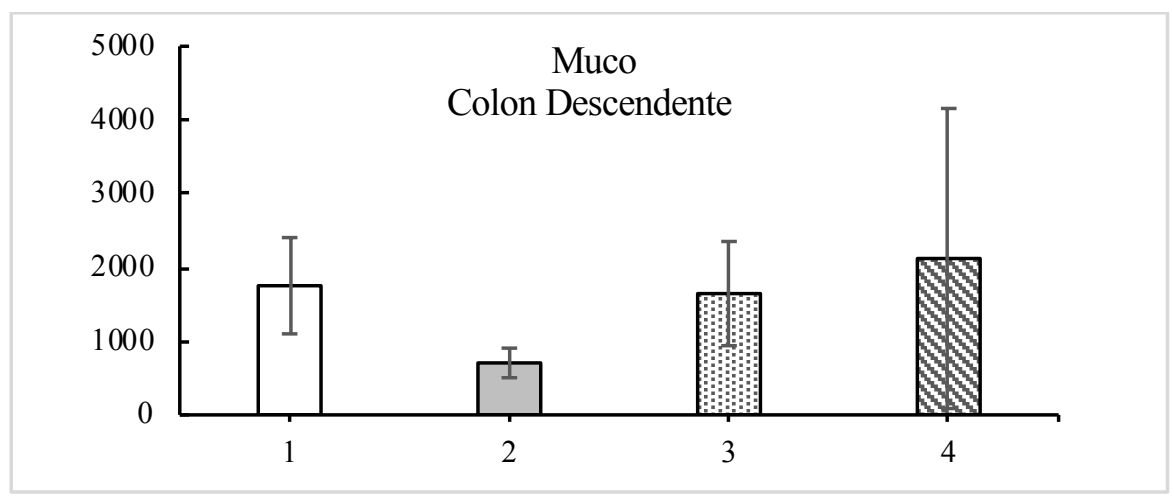

Figura 11- Microscopia Óptica de muco cólon ascendente, grupo 1 - leite, grupo 2 - leite fermentado, grupo 3 - leite bubalino e grupo 4 - leite bubalino fermentado $(\mathrm{P}<0,05)$.

Ao comparar os leites não fermentados percebeu-se que o leite de búfala produz menor quantidade de muco que o leite. Porém, nas matrizes fermentadas bubalina e bovina, notou-se quantidade de muco maior na matriz bubalina fermentada.
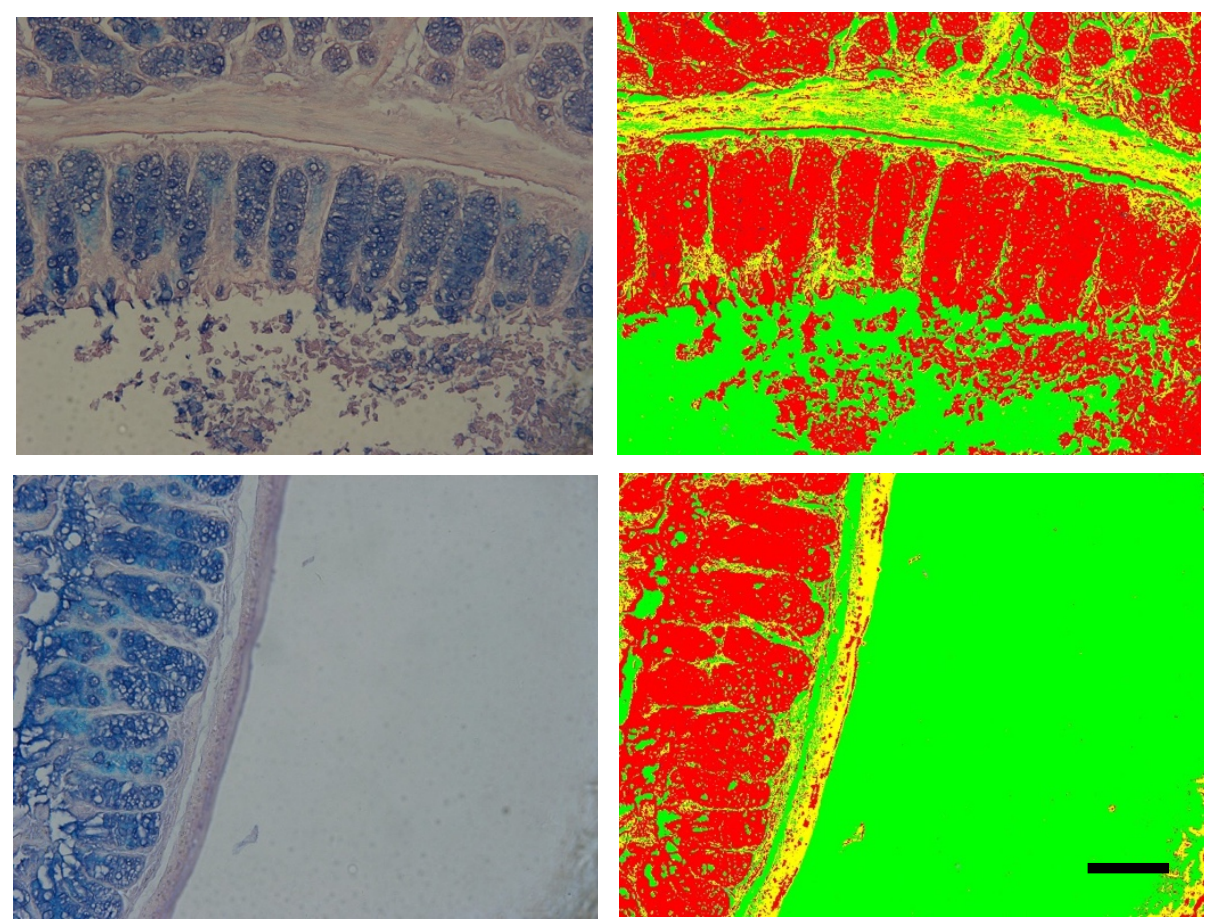

Figura 12 - Histologia de colón ascendente de animais que consumiram leite fermentado por 14 dias, coradas com azul oceano (A - bovino e C - bubalino) mostrando produção de muco e contraste para quantificar em porcentagem as porções de muco em vermelho, mucosa em amarelo e luz em verde (B - bovino e D - bubalino). 
Em relação ao infiltrado celular, o cólon ascendente de animais que consumiram a matriz bovina pasteurizada (1) em relação aos animais que consumiram a matriz bovina fermentada (3), pode-se observar aumento no infiltrado celular naqueles que consumiram a matriz bovina fermentada. Quanto à matriz bubalina, o consumo de leite bubalino pasteurizado (2) em relação ao leite bubalino fermentado (4), não houve diferença significativa em relação ao infiltrado celular (figura 13).

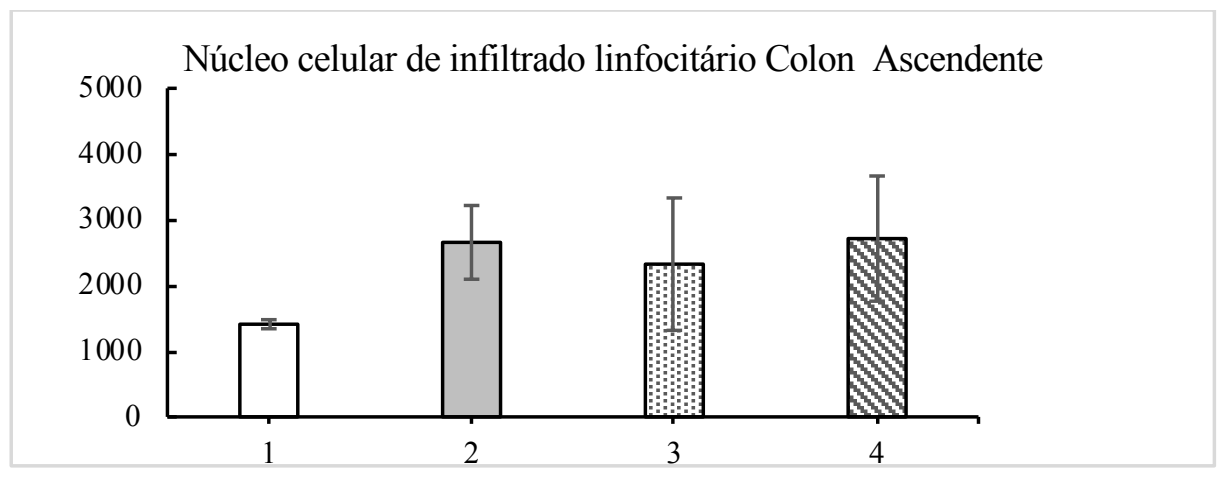

Figura 13- Microscopia Óptica do infiltrtado celular de cólon ascendente, grupo 1 - leite, grupo 2 - leite fermentado, grupo 3 - leite bubalino e grupo 4 - leite bubalino fermentado $(\mathrm{P}<0,05)$.

Há aumento do infiltrado celular na mucosa de animais que consumiram matriz bubalina quando comparada a diferença dos leite e leite de búfala. Porém, ao comparar a matriz bovina fermentada em relação a matriz de búfala fermentada, notou-se aumento no infiltrado célular em cólon ascendente dos animais que consumiram leite de búfala (figura 14).
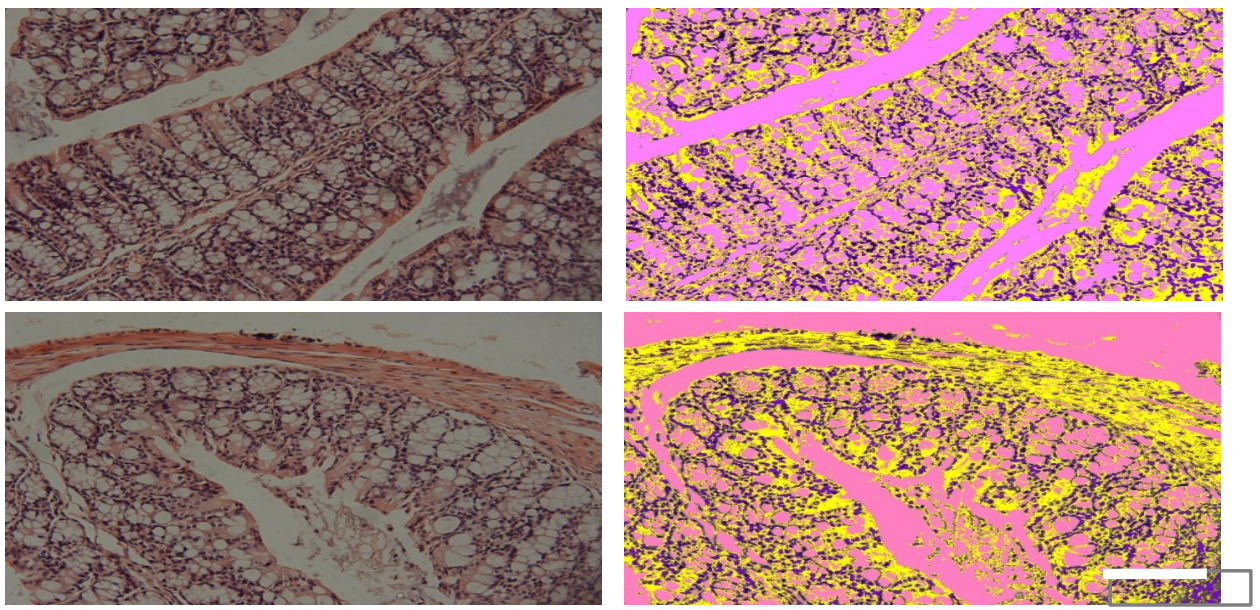

Figura 14 - Histologia de colón ascendente de animais que consumiram leite fermentado por 14 dias, coradas com HE (A- bovino e C- bubalino) mostrando infiltrado celular sendo marcado em roxo o núcleo das células, em amarelo a mucosa e em rosa a luz intestinal (B - bovino e D bubalino). 
Ao comparar a porção do cólon descendente dos animais que consumiram a matriz láctea bovina pasteurizada em relação a matriz láctea bovina fermentada, observou-se a diminuição da porcentagem de células na mucosa dos animais que consumiram a matriz láctea bovina fermentada. Quando comparada à mucosa dos animais que consumiram a matriz bubalina pasteurizada, a mucosa dos animais que consumiram a matriz láctea bubalina fermentada apresentou aumento no infiltrado celular (figura 15).

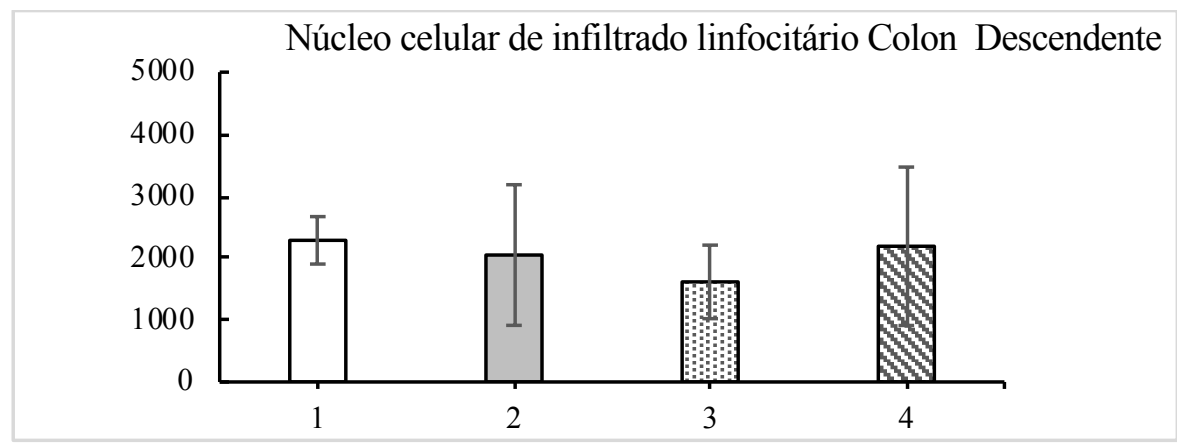

Figura 15- Microscopia Óptica do infiltrtado celular de cólon ascendente, grupo 1 - leite, grupo 2 - leite fermentado, grupo 3 - leite bubalino e grupo 4 - leite bubalino fermentado $(\mathrm{P}<0,05)$.

Os leites pasteurizados de búfala e vaca apresentaram pequena diferença no infiltrado celular, sendo maior na mucosa dos animais que consumiram a matriz láctea bovina. Já para os animais que consumiram as matrizes fermentadas de búfala e vaca, percebeu-se que o consumo de leite fermentado bubalino induz aumento do infiltrado celular (figura 16).
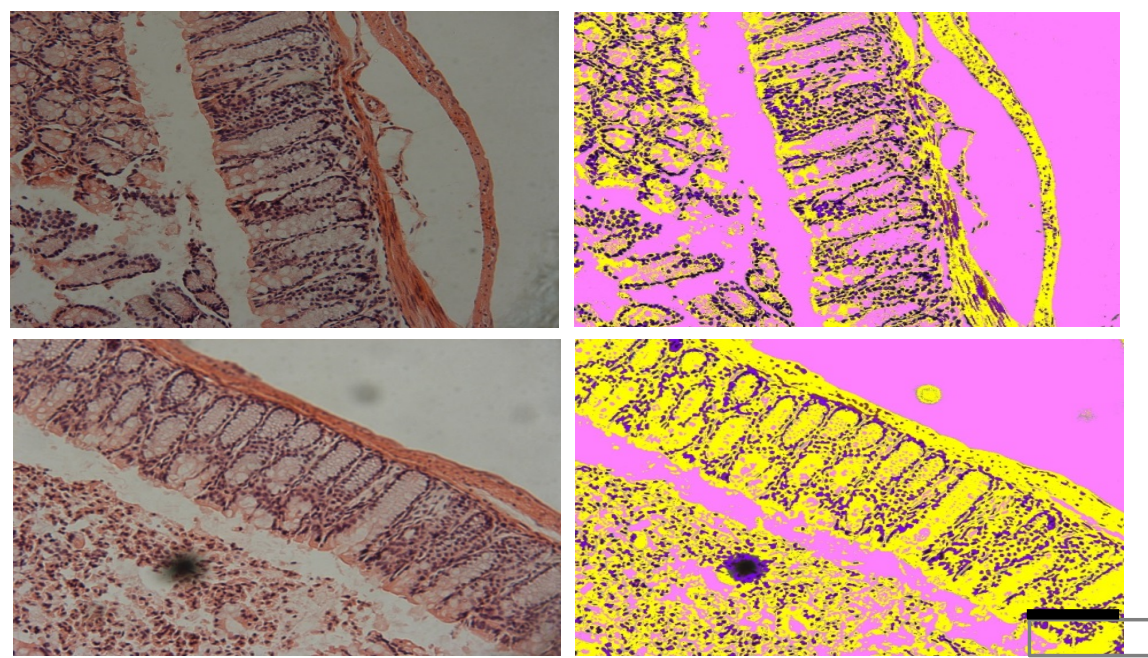

Figura 16 Histologia de colón descendente de animais que consumiram leite fermentado por 14 dias, coradas com HE (A- bovino e C- bubalino) mostrando infiltrado celular sendo marcado em roxo o núcleo das células, em amarelo a mucosa e em rosa a luz intestinal. 


\subsection{Análise por imunofluorescencia do infiltrado linfocitário do cólon de camundongos.}

Após a análise da histologia da mucosa intestinal dos animais tratados com leites pasteurizados e leites fermentados, foi realizada a identificação dos principais tipos celulares que compunham a resposta imune destes animais.

Ao comparar o cólon ascendente dos animais que consumiram matrizes pasteurizadas (grupos 1 e 2) com as amostras dos animais que consumiram matrizes fermentadas (grupo 3 e 4) foi notado que os animais que consumiram leite fermentado não apresentam diferença significativa na porcentagem de plasmócitos produtores de $\operatorname{IgA}$, enquanto que os animais que consumiram a matriz bubalina fermentada, tiveram o dobro de plasmócitos produtores de $\operatorname{IgA}$ do os animais que consumiram o leite bubalino pasteurizado (figura 17).

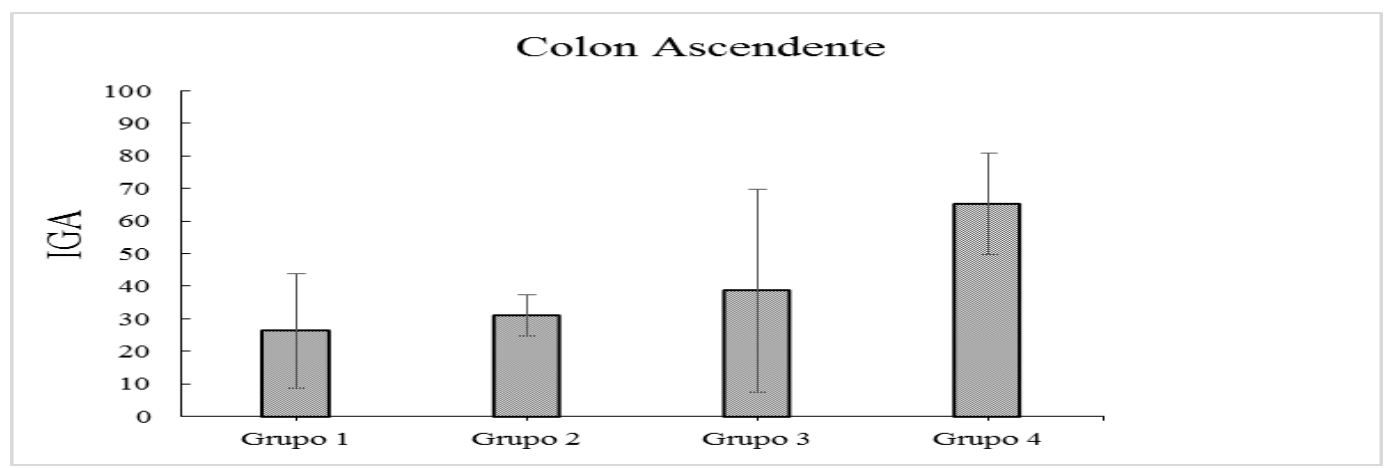

Figura 17 - Microscopia de fluorescencia do infiltrtado celular de cólon ascendente marcado com anticorpo IgA+, grupo 1 - leite, grupo 2 - leite fermentado, grupo 3 - leite bubalino e grupo 4 - leite bubalino fermentado $(\mathrm{P}<0,05)$.

Quando foram comparados os resultados obtidos no colon descendente, os leites pasteurizados de ambas as matrizes não influenciam o número de plasmócitos produtores de IgA presentes na mucosa, no entanto ao fermentar as matrizes, ambas apresentam aumento superior a 30\% no número de plasmócitos presentes após o seu consumo (figura $18)$. 


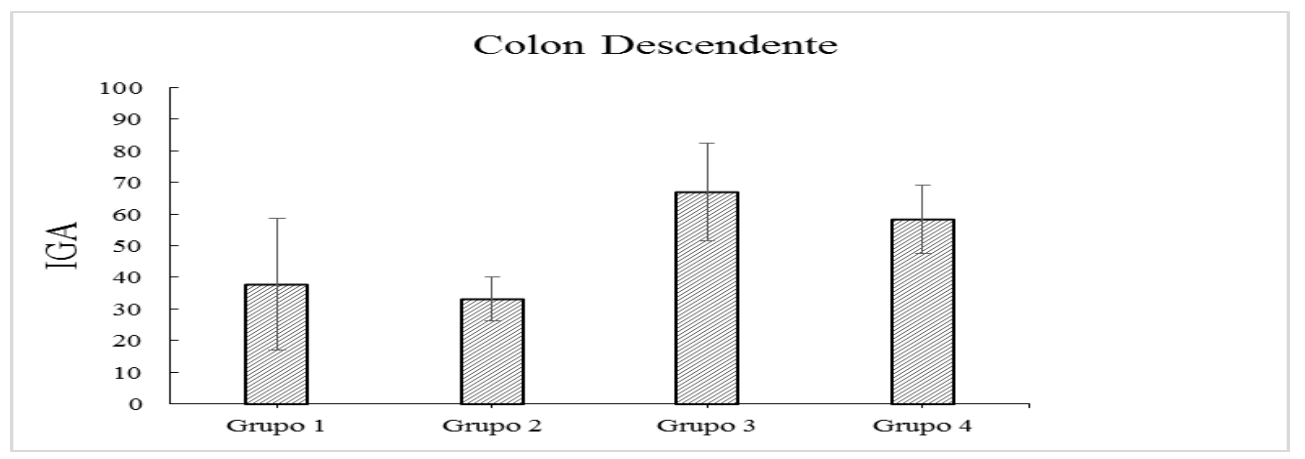

Figura 18- - Microscopia de fluorescencia do infiltrtado celular de cólon ascendente marcado com anticorpo IgA+, grupo 1 - leite, grupo 2 - leite fermentado, grupo 3 - leite bubalino e grupo 4 - leite bubalino fermentado $(\mathrm{P}<0,05)$.

A análise de células B totais na mucosa, representada pela marcação positiva para IgM, mostrou que animais alimentados com leite, leite bubalino ou mesmo com leite fermentado não sofrem alteração no perfil imune em cólon ascendente. No entanto, os animais que consumiram o leite fermentado bubalino, apresentaram aumento na expressão dessas células imunes, indicando que o leite bubalino fermentado é capaz de modular a proliferação de células B. Esta modulação está relacionada com a interferência de microRNAs, no entanto, neste estudo, os microRNAs abordados que trariam esta modulação não estão presentes na matriz alimentar, levando a hipótese de que a modulação ocorre por outro mecanismo de ação. Apesar de não significante, ao contrario do observado no consumo dos alimentos de origem bovina, os alimentos consumidos de origem bubalina apresentaram diferença enquanto fermentado ou não, mostrando discreto aumento na população de células B na mucosa dos animais que consumiram o leite fermentado bubalino (figura 19).

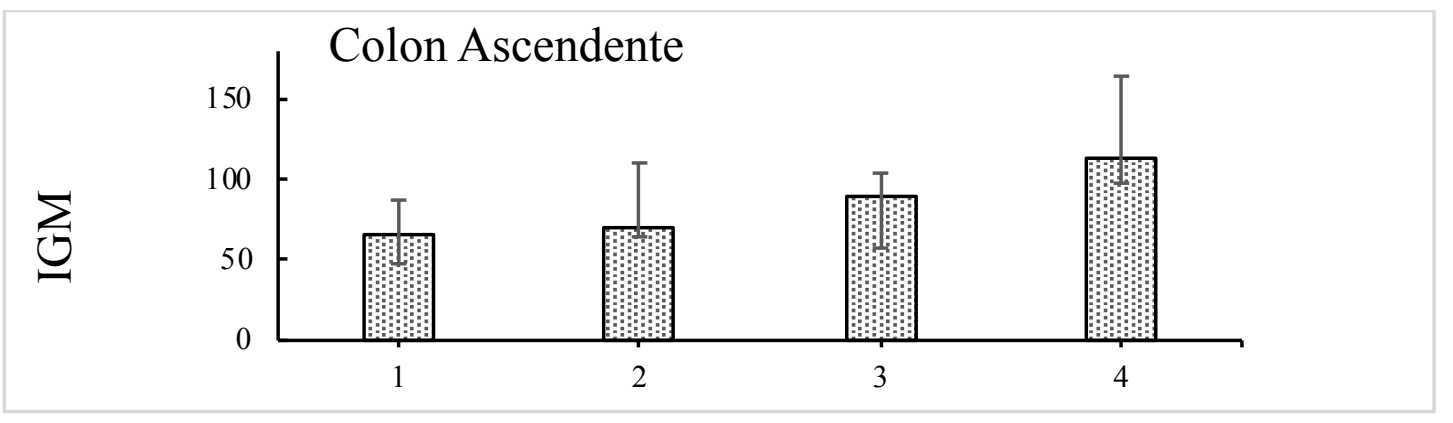

Figura 19 - Microscopia de fluorescencia do infiltrtado celular de cólon ascendente marcado com anticorpo IgM+, grupo 1 - leite, grupo 2 - leite fermentado, grupo 3 - leite bubalino e grupo 4 - leite bubalino fermentado $(\mathrm{P}<0,05)$. 
Em cólon descendente, pode ser observado que tanto as matrizes pasteurizadas quanto as matrizes fermentadas apresentam mesmo padrão no perfil de células B, representando aumento médio de $30 \%$ na porcentagem todal de células B na mucosa intestinal dos animais que consumiram as matrizes fermentadas (figura 20).

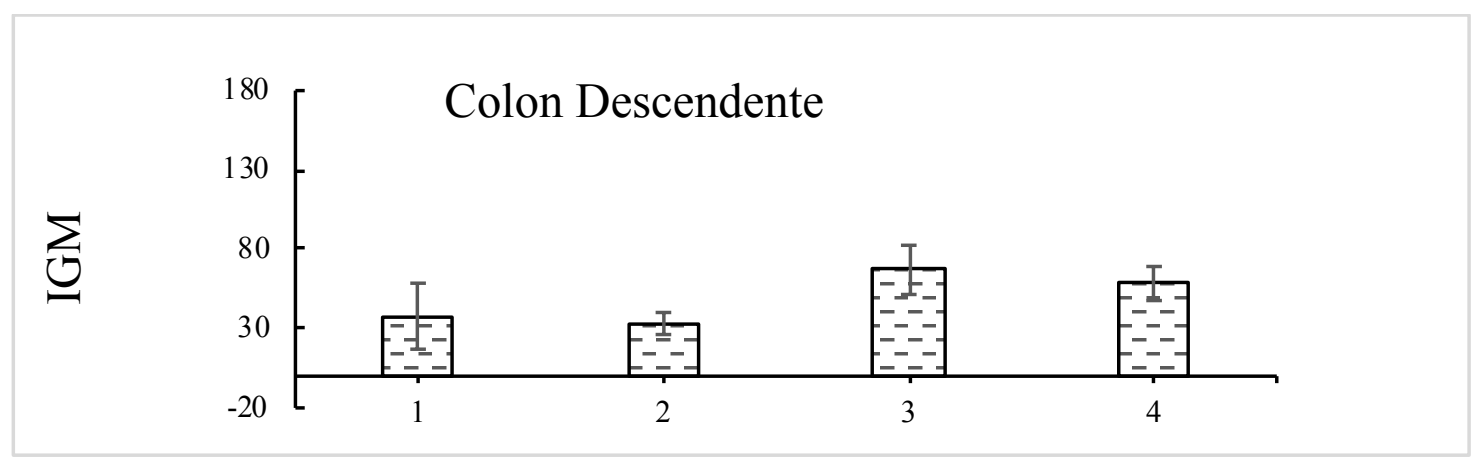

Figura 20 - Microscopia de fluorescencia do infiltrtado celular de cólon descendente marcado com anticorpo IgM+, grupo 1 - leite, grupo 2 - leite fermentado, grupo 3 - leite bubalino e grupo 4 - leite bubalino fermentado $(\mathrm{P}<0,05)$.

A população de fagócitos, representada pelas células marcadas positivamente para o marcador de membrana CD11b, não apresentou, em colon ascendente, sofrer influencia pelo consumo dos produtos lácteos estudados (figura 21), apesar da matriz bubalina pasteurizada (grupo 2), apresentar aumento não significante .quando comparada à matriz láctea bovina (grupo 1).

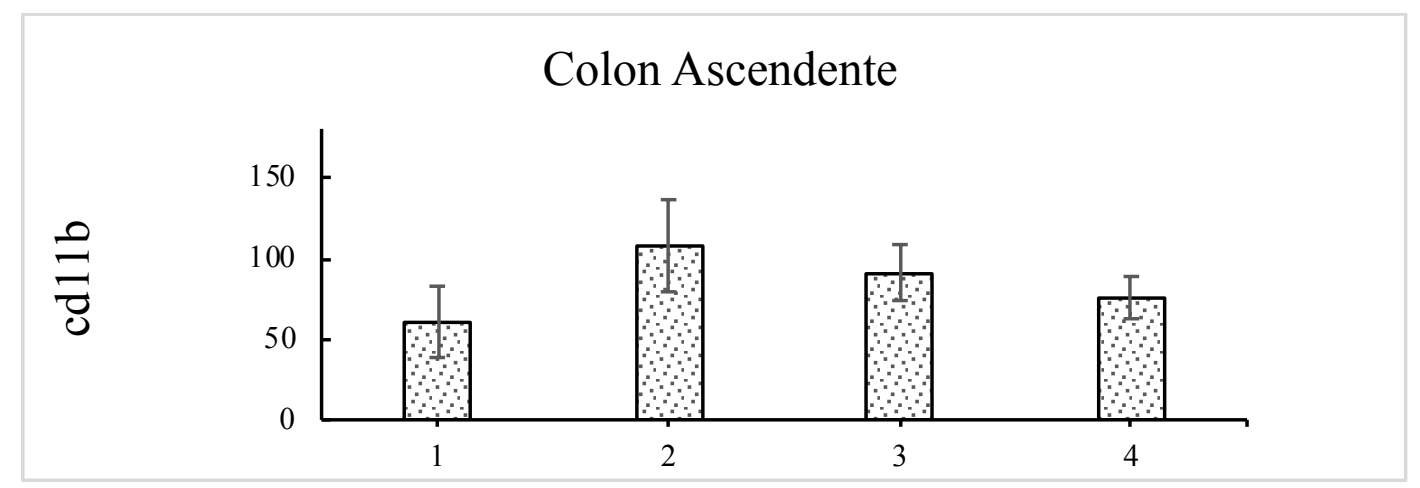

Figura 21- Microscopia de fluorescencia do infiltrtado celular de cólon ascendente marcado com anticorpo $\mathrm{CD} 11 \mathrm{~b}+$, grupo 1 - leite, grupo 2 - leite fermentado, grupo 3 leite bubalino e grupo 4 - leite bubalino fermentado $(\mathrm{P}<0,05)$.

Em colon descendente, a presença de fagócitos CD11+ não sofre influência em sua expressão associada ao consumo dos alimentos lácteos estudados (figura 22). 


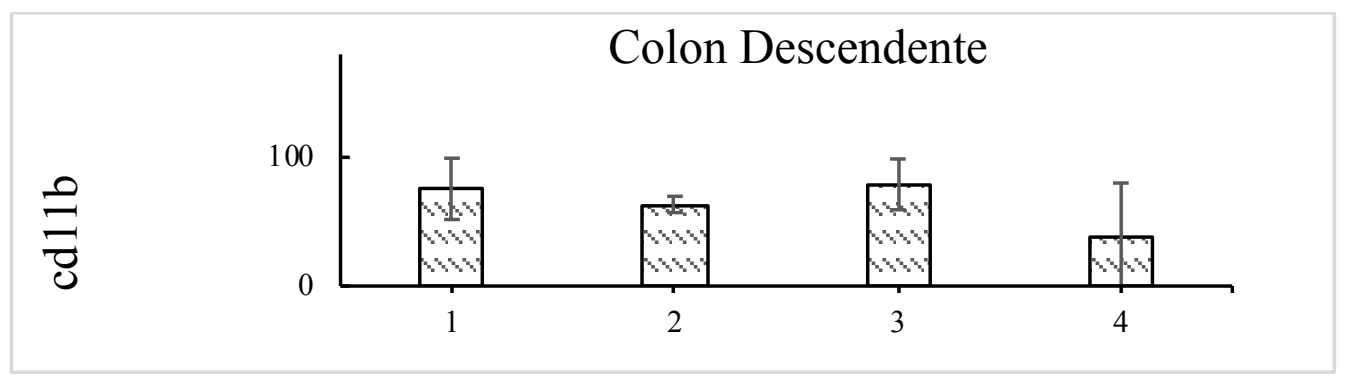

Figura 22- Microscopia de fluorescencia do infiltrtado celular de cólon ascendente marcado com anticorpo $\mathrm{CD} 11 \mathrm{~b}+$, grupo 1 - leite, grupo 2 - leite fermentado, grupo 3 leite bubalino e grupo 4 - leite bubalino fermentado $(\mathrm{P}<0,05)$.

\subsection{Análise por citometria de fluxo do infiltrado linfocitário do cólon do camundongo.}

Após o processo de digestão, soltura e marcação das células do intestino delgado obtido de animais que consumiram leite pasteurizado e fermentado e leite bubalino pasteurizado e fermentado, foi realizada a leitura e identificação do perfil imune celular por citometria de fluxo em aparelho FACScanto no Departamento de Análises Clinicas da Faculdade de Ciências Farmacêuticas - USP.

Os dados obtidos dos experimentos, mostraram que as células marcadas com CD11b, nos parâmetros FSC-AX SSC-A, apresentaram redução na população de fagócitos nos animais que consumiram leite fermentado tanto para a matriz láctea bovina (grupo 3) quanto para a matriz láctea bubalina (grupo 4). A matriz bubalina é capaz de induzir a proliferação de fagócitos 4 vezes mais do que a matriz bovina, se apresentando como alimento potencialmente inflamatório (tabela 2). Os fagócitos, como macrófagos, células dendríticas e células B-1, são células da resposta imune inata, que fagocitam partículas estranhas do hospedeiro e sua presença em órgãos como intestino saudável garantem a homeostasia da microbiota assim como a regulação de patologias da doença inflamatória do intestino (STRAUSS, 2010; PACHECO E CARDOSO,2012; BAIN E MOWAT, 2014). 
Tabela 2- Porcentagem de células fagocíticas marcadas positivamente para CD11b em duodeno de animais que consumiram leite (grupo 1), leite fermentado (grupo 2), leite bubalino (grupo 3) leite bubalino fermentado (grupo 4).

\begin{tabular}{c|cc|}
\hline \multicolumn{3}{|c|}{ celulas/FITC pos } \\
\hline & CD11b & SM \\
\hline Grupo 1 & $4,07 \%$ & $0,89 \%$ \\
Grupo 2 & $16,30 \%$ & $0,15 \%$ \\
Grupo 3 & $1,36 \%$ & $1,25 \%$ \\
Grupo 4 & $8,68 \%$ & $0,77 \%$ \\
\hline
\end{tabular}

Dentre os fagócitos, destacam-se as células dendríticas (DC), marcadas por CD11c em sua maioria. Os parâmetros FSC-AX SSC-A obtidos na identificação de células do duodeno de animais que consumiram os produtos em estudo mostraram um aumento de células dendríticas nos animais que consumiram leite pasteurizado quando comparados aos que consumiram leite fermentado, enquanto os animais que consumiram a matriz bubalina, apresentaram perfil oposto, sendo observado um percentual menor de células dendriticas nos animais que consumiram leite bubalino fermentado (tabela 3 ).

As células dendríticas e macrófagos são células hematopoiéticas consideradas apresentadoras de antígeno, onde as $\mathrm{DC}$ ativam linfócitos $\mathrm{T}$ reguladores iniciando a resposta adptativa (DE JONG, 2005).

Tabela 3 - Porcentagem de células fagocíticas marcadas positivamente para CD11c em duodeno de animais que consumiram leite (grupo 1), leite fermentado (grupo 2), leite bubalino (grupo 3) leite bubalino fermentado (grupo 4).

\begin{tabular}{c|c|c|}
\hline \multicolumn{3}{|c|}{ celulas/Pe pos } \\
& CD11c & SM \\
\hline Grupo 1 & $14,21 \%$ & $0,78 \%$ \\
Grupo 2 & $73,30 \%$ & $0,72 \%$ \\
Grupo 3 & $31,50 \%$ & $1,50 \%$ \\
Grupo 4 & $23,90 \%$ & $0,35 \%$ \\
\hline
\end{tabular}

O marcador de membrana CD3 identifica, nos parâmetros FSC-AX SSC-A, as células T. Quando marcadas duplamente com os receptores de membrana para CD3CD4 
nos parâmetros FSC-AX SSC-A, há a identificação de células T helpers e para CD3CD8, a identificação de células $T$ citotóxicas. As células $T$ são de origem linfóide. Essas $T$ efetoras podem ser T helpers CD4+, que atuam na ativação de outra células e linfócitos, e $\mathrm{T}$ citotóxicas $\mathrm{CD} 8+$, com atividade antitumoral e viral, ambos encontrados na mucosa (BRADLEY, 2003).

Os gráficos informam que no duodeno de animais que consumiram tanto a matriz láctea bovina quanto a bubalina, o percentual de células $\mathrm{T}$ helper é o mesmo, enquanto o perfil de células $\mathrm{T}$ citotóxicas é quatro vezes menor para aqueles animais que consumiram matriz láctea bubalina (Tabela 4). Quanto ao consumo dos produtos fermentados, o perfil de células $\mathrm{T}$ helper apresenta $40 \%$ mais células na matriz bovina que o consumo do leite pasteurizado, no entanto, a matriz bubalina fermentada não altera significativamente $o$ perfil de células $\mathrm{T}$ helper. Já o perfil de células $\mathrm{T}$ citotóxicas, o consumo de produtos fermentados de matriz láctea bovina não interferência na modulação imune enquanto a matriz láctea bubalina aumenta em $20 \%$ o porcentual total de células T CD8+. Esses resultados corroboram coma hipótese de que a matriz bubalina, ao contrário da matriz bovina, promove uma inflamação basal na mucosa, que mantém o sistema imune em estado de alerta, devido aumento do número de células apresentadoras de antígenos e células $\mathrm{T}$ citotóxicas, mas não ativado, pois as células $\mathrm{T}$ helper, que promoverão a diferenciação celular e ativação da resposta, não sofrem alteração, sendo os produtos fermentados derivados de leite bubalino, melhores para a saúde do hospedeiro.

Tabela 4 - Porcentagem de células T helper marcadas positivamente para CD3 e CD4 e de células $\mathrm{T}$ citotóxicas marcadas positivamente para CD3+ e CD8+ em duodeno de animais que consumiram leite (grupo 1), leite fermentado (grupo 2), leite bubalino (grupo 3) leite bubalino fermentado (grupo 4).

\begin{tabular}{|c|c|c|c|c|c|}
\hline \multicolumn{3}{|c|}{ celulas/PE APC pos } & \multicolumn{3}{c|}{ celulas/FITC PE pos } \\
\hline & CD3CD4 & SM & & CD3CD8 & SM \\
\hline Grupo 1 & $51,40 \%$ & $0,88 \%$ & Grupo 1 & $80.40 \%$ & $0,13 \%$ \\
Grupo 2 & $40,60 \%$ & $0,88 \%$ & Grupo 2 & $20,30 \%$ & $0,08 \%$ \\
Grupo 3 & $91,90 \%$ & $0,40 \%$ & Grupo 3 & $86,40 \%$ & $1,62 \%$ \\
Grupo 4 & $31,60 \%$ & $1,04 \%$ & Grupo 4 & $39,70 \%$ & $0,14 \%$ \\
\hline
\end{tabular}

O perfil de células imunes B1a, B1b e B2 não sofreram interferência significativa pelo consumo dos produtos fermentados em ambas as matrizes (dados não mostrados). 


\subsection{Análise estatística}

Os dados experimentais obtidos foram submetidos ao tratamento estatístico utilizando o programa SISTEMA R disponível gratuitamente na rede da universidade. Em todas as análises foram considerados nível de significância $\mathrm{P}<0,5$, sendo as análises utilizando o teste T-Student para dados com 2 grupos e paramétricos e o teste Kruskal-Wallis com dados não paramétricos e mais de 2 grupos. Os valores com $\mathrm{P}<0,5$ foram considerados estatisticamente significativos. 


\section{CONCLUSÃO}

As matrizes lácteas, apresentam mesmo pH e diferença em sua composição de açucares, gorduras e proteínas, sendo a matriz bubalina a que apresenta maior teor de todos os componentes. Esta diferença influencia diretamente o tempo de fermentação, e resposta imune, porém o perfil de pós acidificação e viabilidade dos micro-organismos se manteve igual entre as duas matrizes.

A cepa Bifidobacteirum animalis subsp lactis HN019 apresenta perfil tecnológico superior na matriz bubalina do que na matriz bovina, atingindo tpH5,0 uma hora antes da matriz bovina.

O consumo de leite bubalino pasteurizado produz menos muco que o consumo de leite, no entanto, ao consumir os produtos fermentados, o consumo de matriz bubalina induz maior produção de muco na mucosa intestinal. Esse aumento pode estar associado à maior presença de plasmócitos e células $\mathrm{T}$ efetoras na mucosa de animais que consumiram o leite fermentado bubalino enquanto os fagócitos e células T citotóxicas se apresentam em maior quantidade na mucosa de animais que consumiram os produtos derivados de vaca. Essa observação indica que a matriz bubalina é capaz de modular a resposta imune de maneira anti-inflamatória, sendo um produto melhor a ser consumido por pacientes com doenças inflamatórias intestinais e alérgicas. Durante a investigação do mecanismo de ação promotor desta modulação da resposta imune, as quais acreditouse estarem associadas à presença dos miR-29b, miR-200c, miR-146, miR-155, miR-181a e miR-451, foi realizada a extração dos exossomos em todos os produtos, no entanto sem a presença dos microRNAs de interesse. Acredita-se que os processos térmico e fermentativo tenham degradado esses microRNAs e que não estejam associados à modulação da resposta imune observada. Mais estudos são necessários para identificar esse mecanismo de ação. 


\section{REFERÊNCIAS}

AGYEI, D.; DANQUAH, M. K. Industrial-scale manufacturing of pharmaceutical-grade bioactive peptides. Biotechnology Advances, v. 29, n. 3, p. 272-277, mai./jun. 2011.

AKIRA, S. Toll-like receptors and innate immunity. Adv Immunol, v. 78, p. 1-56, 2001.

ALSAWEED, M.; LAI, C. T.; HARTMANN, P. E.; GEDDES, D.T.; KAKULAS, F. Human milk miRNAs originate mainly from the mammary gland resulting in unique miRNA profiles of fractionated milk. Sci Rep, Sci Rep, v. 6, n. 20680, fev. 2016.

ARUNACHALAM, K. D. Role of Bifidobacteria in nutrition, medicine and technology. Nutrition Research, v.19, n. 10, p. 1559-1597, out. 1999.

ASSOCIAÇÃO BRASILEIRA DE CRIADORES DE BÚFALOS - ABCB. Laticínio: Derivados de leite de búfalas. Disponível em: http://www.bufalo.com.br/laticinios.html. Acesso em: 21 set. 2018.

BADDELA, V.S.; NAYAN, V.; RANI, P.; ONTERU, S.K.; SINGH, D. Physicochemical Biomolecular Insights into Buffalo Milk-Derived Nanovesicles. Appl Biochem Biotechnol, v.178, n. 3, p. 544-57, feb. 2016.

BAIER, S. R.; NGUYEN, C.; XIE, F.; WOOD, JR.; ZEMPLENI, J. MicroRNAs are absorbed in biologically meaningful amounts from nutritionally relevant doses of cow's milk and affect gene expression in peripheral blood mononuclear cells, HEK-293 kidney cell cultures, and mouse livers. J. Nutr., v.144, n. 10, p.1495-1500, out. 2014.

BAIN, C. C.; MOWAT, A. M. Macrophages in intestinal homeostasis and inflammation. Immunological Reviews, v. 260, p.102-117, jul. 2014.

BALLUS, C. A.; KLAJN, V.R.; CUNHA, M.F.; OLIVEIRA, M.L.; FIORENTINI, A.M. Aspectos científicos e tecnológicos do emprego de culturas probióticas na elaboração de produtos lácteos fermentados: revisão. Boletim do Centro de Pesquisa de Processamento de Alimentos, Curitiba, v.28, n.1, p. 85-96, 2010.

BARTEL, D. P. MicroRNAs: genomics, biogenesis, mechanism and function. Cell., v.116, p. 281-297, 2004.

BARTEL, D. P. MicroRNAs: Targeting Recognition and Regulatory Functions. Cell, v. 136, p. 215-233, 2009. 
BAUMJOHANN, D.; ANSEL, K. M. MicroRNA-mediated regulation of T helper cell differentiation and plasticity. Nature Reviews Immunol, v. 13, n. 9, p. 666-78, set. 2013. DOI: $10.1038 /$ nri3494.

BAZZONI, F.; ROSSATO, M.; FABBRI, M.; GAUDIOSI, D.; MIROLO, M.; MORI, L. Induction and regulatory function of miR-9 in human monocytes and neutrophils exposed to proinflammatory signals. Proc Natl Acad Sci U S A, v. 31, n.106, ed.13, p. 5282-7, mar. 2009.

BERNSTEIN, E.; CAUDY, A. A.; HAMMOND, S. M.; HANNON, G. J. Role for a bidentate ribonuclease in the initiation step of RNA interference. Nature, v. 409, n. 6818, p. 363-6, 2001.

BIELECKA, M.; BIEDRZYCKA, E.; MAJKOWSKA, A. Selection of probiotics and prebiotics for synbiotics and confirmation of their in vivo effectiveness. Food

Research International, Amsterdam, v. 35, n. 2/3, p. 125-131, 2002.

BORCHERS, A.T.; SELMI, C.; MEYERS, F. J.; KEEN, C. L.; GERSHWIN, M. E. Probiotics and immunity. J Gastroenterol, v. 44, n. 1, p. 26-46, 2009. DOI: 10.1007/s00535-008-2296-0.

BORGES, K. C.; MEDEIROS, A. C. L.; CORREIA, R. T. P. Iogurte de leite de búfala sabor cajá: caracterização físico-química e aceitação sensorial entre indivíduos de 11 a 16 anos. Alimentos e Nutrição, Marília, v. 20, n. 2, p. 295-300, 2009.

BRADLEY, L. M. Migration and T-lymphocyte effector function. Curr Opin Immunol, v. 15 , n. 3 , p. $343-8,2003$.

BRASIL, R. B. Revisão de Literatura: Proteínas do leite. In: BRASIL, R. B. Estrutura e estabilidade das micelas de caseína do leite bovino. 2013. Seminário. Disciplina de Seminários aplicados do Programa de Pós-graduação em Ciência Animal da Escola de Veterinária e Zootecnia da Universidade Federal de Goiás. 2013, p. 2-3.

BRASIL. Ministério da Agricultura, Pecuária e Abastecimento. Instrução Normativa ${ }^{\circ}$ 46, de 23 de outubro de 2007. Adota o Regulamento Técnico de Identidade e Qualidade de Leites Fermentados, anexo à presente Instrução Normativa. Diário Oficial da República Federativa do Brasil. Brasília, 24 out. 2007. Seção 1, p. 4.

BRASIL. Ministério da Agricultura, Pecuária e Abastecimento Gabinete do Ministro. Instrução Normativa $n^{\circ} 46$, de 23 de outubro de 2007. DOU de 24/10/2007 (nº 205, Seção 1, pág. 4).

BRASIL. Instrução Normativa MAPA no 62 de 29/12/2011. Altera o caput, excluir o parágrafo único e inserir os $\S \S 1^{\circ}$ ao $3^{\circ}$, todos do art. $1^{\circ}$, da Instrução Normativa MAPA $\mathrm{n}^{\mathrm{o}}$ 51, de 18 de setembro de 2002. DO em 30 dez. 2011. Disponível em: 
http://www.normasbrasil.com.br/norma/instrucao-normativa-62-2011_78285.html. Acesso em: 18 de março de 2018

\section{INSTRUÇ̃̃O NORMATIVA No 31, DE 29 DE JUNHO DE 2018 - MAPA}

alimentusconsultoria.com.br/instrucao-normativa-no-31-de-29-de-junho-de-2018-mapa/ Imunidade, 26 (2007) , pp. $133-137$

BRASIL. Instrução Normativa no 31, de 29 de junho de 2018. DOU, 02/07/2018, ed.125, Seção: 1, p. 2. Altera a Instrução Normativa no ${ }^{\circ}$ 62, de 29 de dezembro de 2011. Disponível em: http://www.in.gov.br/materia//asset_publisher/Kujrw0TZC2Mb/content/id/28166433/do1-2018-07-02-instrucaonormativa-n-31-de-29-de-junho-de-2018-28166402. Acesso em: 5 de junho de 2018

BRENNECKE, J.; STARK, A.; RUSSELL, R. B.; COHEN, S. M. Principles of microRNA-target recognition. PLoS Biol. v. 3, n. 3, p. 85, 2005.

BRIGIDI, P.; VITALI, B.; SWENNEN, E.; BAZZOCCHI, G.; MATTEUZZI, D. The effects of probiotic administration on the composition and enzymatic activity of the human fecal microbiota in patients with irritable bowel syndrome or functional diarrhea. Research In Microbiology, v. 152, n. 8, p. 735-741, 2001.

CARVER, J.D.; PIMENTEL, B.; COX, W.I.; BARNESS, L.A. Dietary nucleotides effects upon immune function in infants. Pediatrics, Madison, v. 88, n. 2, p. 359-363, 1991.

CÉ, N.; NORENÃ, C. P. Z.; BRANDELLI, A. Antimicrobial activity of chitosan films containing nisin, peptide P34, and natamycin. CyTA - Journal of Food, v.10, n.1, p. 2126.

CHA, B. K. et al. The effect of a multispecies probiótico mixture on the symptoms and fecal microbiota in diarrhea-dominant irritable bowel syndrome: a randomized, doubleblind, placebo-controlled trial. J Clin Gastroenterol, v. 46, n. 3, p. 220-7, mar. 2012.

CHEN, X. et al. Identification and characterization of microRNAs in raw milk during different periods of lactation, commercial fluid, and powdered milk products. Cell Research, v. 20, n. 10, p.1128-37.

CHERBUT, C. Motor effects of short chain fatty acids and lactate in the gastrointestinal tract. Proc Nutr Soc. v. 62, n 1, p. 95-99, 2003

CHO, W. C. OncomiRs: the discovery and progress of microRNAs in cancers. Mol Cancer, v.6, n.1, p. 60.

CLAEYS, W. L.; LOEY, A. M.; HENDRICKX, M. E. Kinetics of alkaline phosphatase 
and lactoperoxidase inactivation, and of $\beta$-lactoglobulin denaturation in milk with different fat content. Journal of Dairy Research, v. 69, n. 4, p. 541- 553, 2002.

CLAYTON, A.; TURKES, A.; DEWITT, S.; STEADMAN, R.; MASON, M. D.; Hallett, M. B. Adhesion and signaling by Bcell-derived exosomes: The role of integrins. The FASEB Journal, v.18, p. 977-979, 2004.

COPPOLA, M. M.; GIL-TURNES, C. Probióticos e resposta imune. Cienc. Rural, Santa Maria, v. 34, n. 4, p. 1297-1303, aug. 2004.

CURTALE, G.; MIROLO, M.; RENZI, T. A.; ROSSATO, M.; BAZZONI, F.; LOCATI, M. Negative regulation of type 4 receptor signaling by IL-10 dependent microRNA146b. Proc Nat Acad Sci USA, v.110, n. 28, p.11499-504, jul. 2013.

CZERWENKA, C.; MÜLLER, L.; LINDNER, W. Detection of the adulteration of water buffalo milk and mozzarella with cow's milk by liquid chromatographymass spectrometry analysis of $\beta$-lactoglobulin variants. Food Chemistry, Reading, v. 122, n. 1, p. 901-908, out.

2010.

DALOD, M.; CHELBI, R.; MALISSEN, B.; LAWRENCE, T. Dendritic cell maturation: functional specialization through the specification of signaling and transcriptional programming. EMBO J., v.16, n. 33, ed.10, p. 1104-16, mai. 2014.

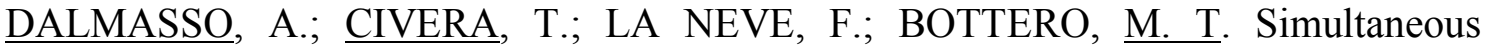
detection of cow and buffalo milk in mozzarella cheese by Real-Time PCR assay. Food Chemistry, v. 124, n. 1, p. 362-36, jan. 2011.

DE ALMADA, C. N; ALMADA, C. N.; MARTINEZ, R. C. R.; SANT'ANA, A. S. Paraprobiotics: Evidences On Their Ability to Modify Biological Responses, Inactivation Methods and Perspectives On Their Application In Foods. Trends in food science \& technology, v. 58, p. 96-114, 2016.

DE JONG, E. C.; SMITS, H. H.; KAPSENBERG, M. L. Dendritic cell-mediated T cell polarization. Springer Semin Immunopathol, v. 26, n. 3, p. 289-307, jan. 2005

DUY, D. N.; LI, R.; DUDEMAINE, P.L.; IBEAGHA-AWEMU, E. M. MicroRNA roles in signalling during lactation: an insight from differential expression, time course and pathway analyses of deep sequence data. Scientific Reports, v. 7, n. 44605, mar. 2017.

DREWNOWSKI, A. The nutrient rich foods index helps to identify healthy, affordable foods.

Am J Clin Nutr, v. 91, n. 4, p. 1095S-1101S, abr. 2010. 
DUBEY, P. C.; SUMAN, C. L.; SANYAL, M. K.; PANDEY, H. S. Factors affecting composition of milk of buffaloes. The Indian journal of animal sciences, v. 67, n. 9, p. 802-804, set. 1997.

EITAN, E.; ZHANG, S.; WITWER, K. W.; MATTSON, M. P. Extracellular vesicledepleted fetal bovine and human sera have reduced capacity to support cell growth. Journal of extracellular vesicles, v. 4, n. 26373, p. 26, mar. 2015.

FECHNER, A.; KIEHNTOPF, M.; JAHREIS, G. The formation of short chain fatty acids is positively associated with the blood lipid lowering effect of lupine tremor fiber in moderately hypercholesterolemic adults. J. Nutr, v. 144, n. 5, p. 599-607, mai. 2014.

FERNANDEZ-VALVERDE, S. L.; TAFT, R. J.; MATTICK, J. S. Dynamic isomiR regulation in Drosophila development. RNA, v, 16, n. 10, p. 1881-8, oct. 2010.

FLORENCE-FRANCO, A. C.; BÉAL, C.; SILVA, R. C.; OLIVEIRA, M. N. Survival of three Bifidobacterium animalis subsp. lactis strains is related to trans-vaccenic and alinolenic and acids contents in organic fermented milks. LWT- Food Science and Technology, v, 56, n. 2, p. 290-295, mai. 2014.

FOOD AND AGRICULTURE ORGANIZATION OF THE UNITED NATIONS - FAO; WORLD HEALTH ORGANIZATION - WHO. Guidelines for the Evaluation of Probiotics in Food. Report of a Joint FAO/WHO Working Group on Drafting Guidelines for the Evaluation of Probiotics in Food, p. 1-11, abr. 2002. Disponível em: http://www.who.int/foodsafety/fsmanagement/en/probioticguidelines.pdf. Acesso em: 20 abril de 2019

FULLER, R.; GIBSON, G. R. Modification of the Intestinal Microflora Using Probiotics and Prebiotics. Scand J Gastroenterol Suppl., v. 222, p. 28-31, 1997.

GALlinA, D.; ANTUNES, A. E. C.; AZAMBUJA-FERREIRA, N. C.; MENDONÇA, J. B., NORBONA, R. A. Caracterização de bebida obtida a partir de leite fermentado simbiótico adicionado de polpa de goiaba e avaliação da viabilidade das bifidobactérias. Revista do Instituto de Laticínios Cândido Tostes, [S.1.], v. 67, n. 386, p. 45-54, dez. 2013.

GANGUli, V. C. Tecnologia de la leche de búfala. Revista Mundial de Zootecnia, Roma, v.30, p. 2-10, 1979.

GAVA, J. A.; SILVA, C. A. B.; FRIAS, J. R. G. Tecnologia dos alimentos: princípios e aplicações. São Paulo: Nobel, 2008. 512 p.

GIBSON, G. R.; WANG, X. Regulatory effects of bifidobacteria on the growth of other 
bacteria of the colon. J Appl Bacteriol, v. 77, p. 412-420, out. 1994.

GILL, S. R. et al. Metagenomic analysis of the human distal gut microbiome. Science, v. 312, n. 5778, p. 1355-1359, jun. 2006. DOI: 10.1126/science.1124234.

GILL, H. S.; RUTHERFURD, K. J.; CROSS, M. L. Dietary probiotic supplementation enhances natural killer cell activity in the elderly: an investigation of age-related immunological changes. J Clin Immunol., v. 21, n. 4, p. 264-71, jul. 2001.

GOLDMAN, A. S. The immune system in human milk and the developing baby. Breastfeed Med, v. 2, n. 4, p.195-204, dec. 2007.

GOMES, A.M.P; MALCATA, X. F. Bifidobacterium ssp. and Lactobacillus acidophilus: Biological, Biochemichal, Technological and Therapeutical Properties Relevant for Use as Probiotics. Trends in Food Science \& Technology, v.10, ed. 4-5, p. 139-157, abr. 1999.

GOODMAN, A.; KALLSTROM, G.; FAITH, J.; REYES, A.; MOORE, A.; DANTAS, G. Extensive personal collections of human intestinal microbiota culture characterized and manipulated in gnotobiotic mice. Proc Natl Acad Sci USA, v. 108, p. 6252-6257, abr. 2011.

GOODRICH, J. et al. Human genetics mold the intestinal microbiome. Cell., v.159, n. 4, p. 789-799, 2014.

GOPAL, P. K; PRASAD, J.; GIL, H. S. Effects of the consumption of Bifidobacterium lactis HN019 and galacto-oligoccharideson the microflora of the gastrointestinal tract in human subjects. Nutrition Research, Tarrytown, v. 23, p. 1313-1328, 2003.

GOPAL, P.K., PRASAD, J., GILL, H.S. Effects of the consumption of Bifidobacterium lactis HN019 (DR10 ${ }^{\mathrm{TM}}$ ) and galacto-oligosaccharides on the microflora of the gastrointestinal tract in human subjects. Nutrition Research, v. 23, n. 10, p. 1313-1328, 2003.

GORDON, D. (Past President, American Academy of Periodontology), Roy Page (University of Washington, Seattle, USA). Prevalence of periodontitis in adults in the United States: 2009 and 2010. J Dent Res, n. 91, p. 914-920, 2012.

GRIFFITHS-JONES, S. miRbase: microRNA sequences and annotation. Curr Protoc Bioinformatics, cap. 12: unid.12.9, p. 1-10, mar. 2010.

GRIFFITHS-JONES, S. The microRNA. Registry.Nucleic acids research, v. 32, p. D109111, jan. 2004. 
GUTTMAN, M.; RINN, J. L. Modular regulatory principles of large non-coding RNAs. Nature, v. 482, n. 7385, p. 339-346, fev. 2012.

H. Izumi , M. Tsuda , Y. Sato, N. Kosaka, T. Ochiya, H. Iwamoto, et al. Os exossomos de leite bovino contêm microRNA e mRNA e são absorvidos por macrófagos humanos

HASCHKE, F. et al. Ensaios clínicos comprovam a segurança e a eficácia da cepa probiótica Bifidobacterium $\mathrm{Bb} 12$ na fórmula de acompanhamento e leites de crescimento. Monatsschr Kinderheikd, 146, 26s-30s, 1998.

HEIL, F. et al. Species-Specific Recognition of Single-Stranded RNA via Toll-like receptor 7 and 8. Science, v. 303, n. 5663, p. 1526-9, fev. 2004

HILL, C. et al. Expert consensus document: The International Scientific Association for Probiotics and Prebiotics consensus statement on the scope and appropriate use of the term probiotic. Nature Reviews Gastroenterology \& Hepatology, v.11, n. 8, p. 506514, ago. 2014.

HODDINOTT, P.; TAPPIN, D.; WRIGHT, C. Breast feeding. BMJ, v. 336, p. 881-887, abr. p. 2008.

HÜHN, S. et al. Estudo comparativo da composição química do leite de zebuínos e bubalinos. Belém: EMBRAPA-CPATU.EMBRAPA-CPATU. Boletim de Pesquisa, n. 36, 15p., 1982.

INSTITUTO BRASILEIRO DE GEOGRAFIA E ESTATÍSTICA - IBGE. Pesquisa de Orçamentos Familiares 2008-2009. Aquisição Alimentar Domiciliar Per Capita: Brasil e Grandes Regiões. Rio de Janeiro: IBGE, 2010.

IP, C.; PARIZA, M. CLA (Conjugated Linoleic Acid). In: Interpretative review of recent nutrition research. Disponível em: www.nationaldairycouncil.org. Acesso em: 25 out. 2017.

IRMAK, M. K.; OZTAS, Y.; OZTAS, E. Integration of maternal genome into the neonate genome through breast milk mRNA transcripts and reverse transcriptase. Theoretical Biology \& Medical Modelling, v. 9, n. 20, p. 1-8, jun. 2012.

IZUMI, H. et al. Bovine milk contains microRNA and messenger RNA that are stable under degradative conditions. J Dairy Sci, v. 95, p. 4831-41, 2012.

KAJANDER, K. et al. Clinical trial: multispecies probiotic supplementation relieves symptoms of irritable bowel syndrome and stabilizes intestinal microbiota. Aliment Pharmacol Ther, v. 27, n. 1, p. 48-57, jan. 2008. 
KARLSSON, M. et al. "Tolerosomes" are produced by intestinal epithelial cells. European Journal of Immunology, v. 31, n. 10, p. 2892-2900, out. 2001.

KASUBUCHI, M.; HASEGAWA, A.; HIRAMATSU, T. Intestinal microbial metabolism, short chain fatty acids and metabolic regulation of the host. Nutrients, v. 7, n. 4 , p. $2839-49$, abr. 2015.

KIRCHNER, B.; PFAFFL, M. W.; DUMPLER, J.; von MUTIUS, E.; EGE, M. J. MicroRNA in native and processed cow's milk and its implication for the effect of fifth milk in asthma. J. Allergy Clin. Immunol, v. 137, n. 6, p. 1893-1895 e 13, jun. 2016.

KLAENHAMMER, T. R. Probiotics and prebiotics. In: DOYLE, M. P.; BEUCHAT, L. R.; MONTVILLE, T. J. Food microbiology: fundamentals and frontiers. 2.ed. Washington: ASM, 2001. p.797-811.

KOSAKA, N.; IZUMI, H.; SEKINE, K.; OCHIYA, T. microRNA as a new immuneregulatory agent in breast milk. Silence, v. 1; n. 1, p. 7, mar. 2010.

KRAMER, M. S. Breast is best: The evidence. Early Hum Dev, v. 86, n. 11, p. 729-32, nov. 2010.

KURODA, A. et al. Insulin gene expression is regulated by DNA methylation. PLoS One, v. 4, n. 9, p. e6953, set. 2009.

LAU, N. C.; LIM, L. P.; WEINSTEIN, E. G.; BARTEL, D. P. An abundant class of tiny RNAs with probable regulatory roles in Caenorhabditis elegans. Science, v. 294, n. 5543 , p. 858-62, out. 2001.

LEE, R. C.; AMBROS, V. An extensive class of small RNAs in Caenorhabditis elegans. Science, v. 294, n 5543, p. 862-864, out. 2001.

LEE, R. C.; FEINBAUM, R.L; AMBROS, V. The C. elegans heterochronic gene lin4 encodes small RNAs with antisense complementarity to lin-14. Cell, v. 75, p. 843-854, 1993.

LEE, Y. et al. The nuclear RNase III Drosha initiates microRNA processing. Nature, v. 425, n. 6956, p. 415-9, set. 2003.

LEE, Y. et al. MicroRNA genes are transcribed by RNA polymerase II. EMBO J, v. 23, n. 20, p. 4051-4060, out. 2004.

LEROY, F.; VUYST, L. Lactic acid bacteria as functional starter cultures for the food 
fermentation industry. Trends in Food Science \& Technology, v. 15, n. 2, p. 67-78, 2004.

LEY, R.; BÄCKHED, F.; TURNBAUGH, P.; LOZUPONE, C. A.; KNIGHT, R. D. Obesity alters gut microbial ecology. Proc Natl Acad Sci U S A, v. 102, n. 31, p. 110705, aug. 2005.

LI, R. et al. Deep sequencing shows microRNA involvement in bovine mammary gland adaptation to diets supplemented with linseed oil or safflower oil. BMC Genomics, v. 16, p. 884-884, out. 2015.

LI, Z. et al. Biological functions of miR-29b contribute to positive regulation of osteoblast differentiation. J Biol Chem, v. 284, n. 23, p. 15676-84, 2009.

LI, Z.; LIU, H.; JIN, X.; LO, L.; LIU, J. Expression profiles of microRNAs from lactating and non-lactating bovine mammary glands and identification of miRNA related to lactation. BMC Genomics, n.13, p. 731, dez. 2012.

LIMA, M. S. F.; SILVA, R. A.; SILVA, M. F.; PORTO, A. L. F.; CAVALCANTI, M. T. H. CARACTERÍSTICAS MICROBIOLÓGICAS E ANTIOXIDANTES DE UM NOVO ALIMENTO FUNCIONAL PROBIÓTICO: LEITE DE OVELHA FERMENTADO POR KEFIR, p. 3673-3680. In: Anais do XX Congresso Brasileiro de Engenharia Química - COBEQ 2014 [Blucher Chemical Engineering Proceedings, v.1, n.2]. São Paulo: Blucher, 2015.

LINK, J. et al. Food-Derived Xeno-microRNAs: Influence of Diet and Detectability in Gastrointestinal Tract- Proof-of-Principle Study. Molecular Nutrition \& Food Research, v. 63, n. 2, out. 2018.

LIONG, M.T.; SHAH, N.P. Acid and bile tolerance and cholesterol removal ability of lactobacilli strains. Journal of Dairy Science, v. 88, n. 1, p. 55-66, jan. 2005.

LUND, E.; GUTTINGER, S.; CALADO, A.; DAHLBERG, J. E.; KUTAY, U. Nuclear export of microRNA precursors. Science, v. 303, n. 5654, p. 95-8, jan. 2004.

LUND, J. M. et al. Recognition of single-stranded RNA viruses by Toll-like receptor 7. Proc Natl Acad Sci USA, v. 101, p. 5598-5603, abr. 2004.

MALISSEN, B.; TAMOUTOUNOUR, S.; HENRI, S. The origins and functions of dendritic cells and macrophages in the skin. Nat Rev Immunol, v.14, p. 417-28, jun. 2014.

MARCO, M. L.; PAVAN, S.; KLEEREBEZEM, M. To understand the molecular modes of probiotic action. Curr Opin Biotechnol, v. 2, p. 204-10, abr. 2006. 
MATSUMOTO, S. et al. Probiotic Lactobacillus-induced improvement in murine chronic inflammatory bowel disease is associated with the down-regulation of pro-inflammatory cytokines in lamina propria monoclear cell. Clin Exp Immunol, v.140, n. 3, p. 417-26, jun. 2005.

MILDNER, A.; JUNG, S. Development and function of dendritic cell subsets. Imunidade, v. 40, p. 642-56, mai. 2014.

MILLER, L. E.; LEHTORANTA, L.; LEHTINEN, M. J. The Effect of Bifidobacterium animalis ssp. lactis HN019 on Cellular Immune Function in Healthy Elderly Subjects: Systematic Review and Meta-Analysis. Nutrients, v. 9, n. 3, p. E191, fev. 2017.

MÖLLER, N. P.; SCHOLZ-AHRENS, K. E.; ROOS, N.; SCHREZENMEIR, J. Bioactive peptides and proteins from foods: indication for health effects. Eur J Nutr, v. 47, n. 4, p. 171-82, jun. 2008.

MULCAHY, L. A.; PINK, R. C.; CARTER, D. R. Routes and mechanisms of extracellular vesicle uptake. J Extracell Vesicles, v. 4, n. 3, ago. 2014, eCollecton.

MUNIQUE, S.; SOBO-VUJANOVIC. A.; BUSCHSER, W. J.; BEER-STOLZ, D.; VUJANOVIC, N. L. Dendritic cell exosomes directly kill tumor cells and activate natural killer cells through TNF superfamily ligands. Oncoimunologia, v.1, n. 7, p. 1074-1083, out. 2012.

MUTIUS, E. Exposição materna / ingestão de leite de vaca não pasteurizado e doença alérgica. Curr. Opin. Gastroenterol. 2012, 28 , 570 - 576.

NASCIMENTO, C. N. B.; CARVALHO, L. O. M. Criação de Búfalos: Alimentação, Manejo, Melhoramento e Instalações. Brasília: EMBRAPA/SPI, 1993. 403 p.

NEGRINI, M.; NICOLOSO, M. S.; CALIN, G. A. MicroRNAs and cancer--new paradigms in molecular oncology. Curr Opin Cell Biol, v. 21, n. 3, p. 470-479, jun. 2009.

NEUTRA, M. R.; N. J. MANTIS. eutra, M. R., N. J.et al. Collaboration of epithelial cells with organized mucosalon the fecal microbiota of humans. Applied and Environmental Microbiology, v. 70, n. 4, p. 2129- 2005.

NEWBURG, D. S.; WALKER, W. A. Protection of the neonate by the innate immune system of developing gut and of human milk. Pediatr Res, v. 61, n. 1, p. 2-8, jan. 2007.

OLIVEIRA, R. P. S. et al. Effect of different prebiotics on the fermentation kinetics, probiotic survival and fatty acids profiles in non-faty synbiotic fermented milk. 
International jornal of food Microbiology, v.128, n. 3, p. 467- 472, 2009.

ORDÓÑEZ, J. A. et al. Tecnologia de Alimentos - Alimentos de Origem Animal. Tradução de Fátima Murad. Porto Alegre: Artmed, 2005. v. 2, 279 p.

ORGANIZAÇÃO MUNDIAL DE GASTROENTEROLOGIA - OMGE. Guias práticas: Probióticos e Prebióticos, p. 1-22, mai., 2008. p.1-22.

OUNI, M. et al. The P2 promoter of the IGF1 gene is a major epigenetic locus for GH responsiveness. The pharmacogenomics journal, v. 16, n. 1, p. 102-6, 2015.

OUNI, M. et al. The IGF1 P2 promoter is an epigenetic QTL for circulating IGF1 and human growth. Clin Epigenetics, v. 7, p. 22, mar. 2015. eCollection.

PACHECO, F. C. E CARDOSO, E. M. Imunidade inata e inflamação. In: AROSA, F. A.; CARDOSO, E. M.; PACHECO, F. C. Fundamentos de imunologia. Lisboa: LIDEL, 2012, $615 \mathrm{p}$.

PALMQUIST, D. L. Ruminal and endogenous synthesis of CLA in cows. Aust. J. Dairy Technol, v. 56 p.134-137, 2001.

PARIZA, M. W.; PARK, Y., COOK, M. Conjugated linoleic acid and the control of cancer and obesity. Toxicological Sciences, v. 52, p. 107-110, 1999.

PARKIN, J.; COHEN, B. An overview of the immune system. Lancet., v. 357, n. 927, p. 1777-89, jun. 2001

PATEL, P. J.; SINGH, S. K.; PANAICH, S.; CARDOZO, L. The aging gut and the role of prebiotics, probiotics, and synbiotics: a review. J Clin Gerontol Geriatr, v. 5, n. 1, p. 3-6, mar. 2014.

PIMENTEL, G. D.; BARBALHO, S. M. Probióticos no tratamento do câncer: aspectos atuais. Nutrição em Pauta, São Paulo, v. 15, n. 54, mai.jun. 2007.

PROTIC, M. et al. Mechanism of diarrhea in microscopic colitis. World Journal of Gastroenterology, v.11, n 35, p. 5535-5539, set. 2005.

QJ, L. et al. miR-181a is an intrinsic modulator of T cell sensitivity and selection. Cell, v.129, p. 147-161, abr. 2007.

RAMOS, A.C.S.M. et al. Elaboração de Bebidas Lácteas Fermentadas: Aceitabilidade e Viabilidade de Culturas Probióticas. Ciências Agrárias. Londrina, v. 34, n. 6, p. 28172828, nov./dez., 2013. 
RANA, T. M. Illuminating the silence: understanding the structure and function of small RNAs. Nat Rev Mol Cell Biol., v. 8, n. 1, p. 23-36.

RAPOSO, G.et al. B lymphocytes secrete antigen-presenting vesicles. J Exp Med., v. 183, n. 3, p. 1161-72, mar. 1996.

RAPOSO, G., STOORVOGEL, W. Extracellular vesicles: exossomes, microvesicles, and friends. J. Cell Biol., v. 200, n. 46, p. 40174-40183, nov. 2011.

RIBEIRO, M. G. Princípios terapêuticos na mastite em animais de produção e de companhia. In: ANDRADE, S.F. (Ed). Manual de terapêutica veterinária. 3. ed. Roca: São Paulo, 2008. 936 p.

ROSE, A. H. Yeast, a microorganism for all species: a theoretical look at its mod of action. In: LYONS, T.P. (Ed.). Biotechnology in the feed industry. Nicholasville: Alltech Technical, 1997. p.113-118.

ROSSATO, M. et al. IL-10-induced microARN-187 negatively governs the production of TNF- $\alpha$, IL-6 and IL-12p40 in TLR4-stimulated monocytes. Proc Natl Acad Sci EUA., v. 109, n. 45, p. E3101, NOV. 2012.

ROSSI, M. et al. miR-29b negatively regulates human osteoclastic cell differentiation and function: Implications for the treatment of multiple myeloma-related bone disease. $\mathbf{J}$ Cell Physiol., v. 228, p. 1506-15.

SAAD, S.M. I. Probióticos e prebióticos: o estado da arte. Rev. Bras. Cienc. Farm. [online]. v. 42, n.1, p.1-16, 2006.

SACCARO, D. M., HIROTA, C. Y., TAMIME, A. Y., OLIVEIRA, M. N. Evaluation of different selective media for enumeration of probiotic micro- organisms in combination with yogurt starter cultures in fermented milk. Afr J Microbiol Res, v. 46, p. 3901- 3906, 2011.

SALMINEN, S.; SALMINEN, E. Lactulose, Lactic Acid Bacteria, Intestinal Microecology and Mucosal protection. Scand J Gastroenterol Suppl., n. 222, p. 45-8, 1997.

SANDERS, M.E.; KLAENHAMMER, T.R. Invited review: the scientific basis of Lactobacillus acidophilus NCFM functionality as a probiotic. J. Dairy Sci., Savoy, v.84, p.319-331, 2001.

SCHWARZ, D.S. et al. Asymmetry in the assembly of the RNAi enzyme complex. Cell., v. 115, n. 2, p. 199-208, out. 2003. 
SGARBIERI, V. C. Revisão: Propriedades Estruturais e Físico Químicas das Proteínas do Leite. Brazilian Journal of Food Technology, Campinas, v.8, p. 43-56, 2005.

SILVA, A. M. et al. Effect of Bifidobacterium longum ingestion on experimental salmonellosis in mice. Journal of Applied Microbiology., v. 197, n 1, p. 29-37, 2004.

SINDHU, J. S; SINGHAL, O. P. Qualitative aspects of buffalo milk constituents for products technology. II World Buffalo Congress, New Delhi - India, p. 263-81, 1988.

SIRAN, Y.; ZHEHAO, Z.; LIMING, S.; PING, L. Fermentation results in quantitative changes in milk - derived exossomes and diferente effects on cell growth and survival. $\underline{\mathbf{J}}$ Agric Food Chem., v. 65, n. 6, p. 1220-1228, fev. 2017.

SMYTH, L. A., et al. MicroRNAs affect the function of dendritic cells and the phenotype. Immunology., v. 144, n. 2, p. 197-205, fev.; 2015. DOI: 10.1111/imm.12390.

TILI E, MICHAILLE JJ, CALIN GA.(2008). Expression and function of micro-RNAs in immune cells in normal state or disease. Int J Med Sci., v. 5, n. 2, p. 73-79, 2008.

TOJO, R. et al. Intestinal microbiota in health and disease: role of bifidobacteria in gut homeostasis. World J Gastroenterol., v. 20, p. 15163-15176, nov. p. 2014.

TOMBINI, H. et al. Consumo de leite de vaca e derivados entre agricultores da região oeste do Paraná. Alimentação e Nutrição, Araraquara, v. 23, n. 2, p. 267-274, 2012.

TORREGROSA, P. P.; GUTZEIT, C.; JOHANSSON, S.; ADMYRE, C.; STENIUS, F. Differences in exosome populations in human breast milk in relation to allergic sensitization and lifestyle. European Journal of Allergy and Clinical Immunology, v. 69, p. 463- 471, abr. 2014.

TURRONI, F. et al. Bifidobacterium bifidum as an example of a specialized human tripod. Front Microbiol., v. 5, p. 437, ago. 2014.

US Department of Agriculture (USDA) and US Department of Health and Human Services. Dietary Guidelines for Americans, 2010. [ internet]. [acesso em 25 de outubro de 2017]. 7th Edition, Washington, DC: U.S. Government Printing Office, December; 2010. Disponível em: http:/health.gov/dietaryguidelines/2010/. Acesso em: 6 de fevereiro de 2018

VALADI, H. et al. Exosome-mediated transfer of mRNAs and microRNAs is a novel mechanism of genetic exchange between cells. Nat Cell Biol., v. 9, p. 654-659, 2007.

VALENCIA-SANCHEZ, M. A.; LIU, J.; HANNON, G. J.; PARKER, R. Control of 
translation and mRNA degradation by miRNAs and siRNAs. Genes Dev., v. 20, n. 5, p. 515-24, mar. 2006.

VEIGA, G.V. et al. Inadequação do consumo de nutrientes entre adolescentes brasileiros. Rev Saúde Pública, v. 47, n. 1, p. 2012S-21S, 2013.

VERRUMA, M. R.; SALGADO, J. M. Análise química do leite de búfala em comparação ao leite de vaca. Sci Agric, (Piracicaba, Braz.) [online]. v. 51, p.131-137, 1994.

VIANNI, M.C.E. et al. Eficiência do California Mastitis Test (CMT) na estimativa do número de células somáticas do leite bubalino. Revista Ciência Veterinária, v.4. p.3-4, 1999.

VICKERS, K.C.; SETHUPATHY, P.; BARAN-GALE. J.; REMALEY, A. T. Complexity of microRNA function and the role of isomiRs in lipid homeostasis. Journal of lipid research., 54, n. 5, p. 1182-91, mai. 2013.

WANG, D. et al. Systematic microRNAome profiling reveals the roles of microRNAs in milk protein metabolism and quality: insights on low-quality forage utilization. Scientific reports., v. 6, p. 21194, 2016.

WANG, W., MEJIA, E. G. A new frontier in soy bioactive peptides that may prevent agerelated chronic diseases. Comprehensive Reviews in Food Science and Food Safety, v. 4, n. 4, p. 63-78, 2005.

WEBER J. A. et al. The microRNA spectrum in 12 body fluids. Clin Chem, v. 56, p. 1733-1741, nov. 2010.

WALLER, P. A. et al. Dose-response effect of Bifidobacterium lactis HN019 on whole gut transit time and functional gastrointestinal symptoms in adults. Scand $J$ Gastroenterol., v. 46, n. 9, p. 1057-64, set. 2011.

WITWER, K. W. et al. Real-time quantitative PCR and droplet digital PCR for plant miRNAs in mammalian blood provide little evidence for general uptake of dietary miRNAs, RNA Biology, v. 10, n. 7, p. 1080-6, 2013.

XIAO C, et al. MiR-150 controls the differentiation of B cells targeting the c-Myb transcription factor. Cell., v. 13, n. 1, p. 146-59.

XIAO, C.; RAJEWSKY, K. MicroRNA control in the immune system: basic principles. Cell, v. 136, n. 1, p. 26-36, jan. 2009.

XIE, F. L.; STEWART, N.; TAKI, F. A.; HE, Q. L.; LIU, H. W; ZHANG, B. H. High throughput deep sequencing shows that microRNAs play important roles in switchgrass 
responses to drought and salinity stress. Plant Biotechnology Journal, v. 12, n. 3, p. 354366, abr. 2014.

XU, Z. et al. MiR-365, a Novel Negative Regulator of Interleukin-6 Gene Expression, Is Cooperatively Regulated by Sp1 and NF-kB. J BiolChem, v. 286, n. 24, p. 21401-21412, abr. p. 2011.

YE, A. Functional properties of milk protein concentrates: Emulsifying properties, adsorption and stability of emulsions. International Dairy Journal, v. 21, p. 14-20, 2011.

YOON, J. H.; ABDELMOHSEN, K.; GOROSPE, M. Post-transcription regulation of the gene by long uncoded RNA. J Mol Biol, v. 425, n. 19, p. 3723-30, out. 2013.

YOSHIKAWA, M.; TAKAHASHI, M.; YANG, S. Delta opioid peptides derived from plant proteins. Curr. Pharm. Des., v. 32, n. 2, p. 1325-1330.

ZEN, K.; ZHANG, C. Y. Circulating microRNAs: a new class of biomarkers to diagnose and monitor human cancer. Med Res Rev, v. 32, n. 2, p. 326-348, mar. 2012.

ZHANG, L. et al. Exogenous plant MIR168a specifically targets mammalian LDLRAP1: evidence of cross-kingdom regulation by microRNA. Cell Res, v. 22, n. 1, p. 107-26, jan. 2012.

ZHOU, Y.et al. The potential role of epigenetic modifications in the heritability of multiple sclerosis. Multiple Sclerosis Journal, Hobart, v. 20, n. 2, p. 135-140, 2014.

ZHOU, J. S.; RUTHERFURD, K. J.; GILL, H. S. Inability of Probiotic Bacterial Strains Lactobacillus rhamnosus HN001 and Bifidobacterium lactis HN019 To Induce Human Platelet Aggregation In Vitro. Journal of Food Protection, v. 68, n.11, p. 2459-2464, nov. 2005. 
ANEXOS 
Anexo 1 - Aprovação da CEUA para o uso dos animais neste experimento.

\title{
UNIVERSIDADE DE SÃO PAULO
}

FACULDADE DE CIÊNCIAS FARMACÊUTICAS

Comissão de Ética no Uso de Animais - CEUA

CEUAFCF 036.2018-P564

\section{CERTIFICADO}

Certificamos que a proposta intitulada estudo comparativo da matriz láctea e bubalina na identificação de micro rnas imumoduladores frente ao processo de fermentação por bactérias probióticas, registrada com - $n^{\circ} 564$, sob a responsabilidade do(a) pesquisador(a) Alessandra Prestes, sob orientação do(a) Profa. Dra. Cristina Stewart Bittencourt Bogsan - que envolve produção ou manutenção ou utilização de animais pertencentes ao filo Chordata, subfilo Vertebrata (exceto humanos), para fins de pesquisa cientifica - encontrase de acordo com os preceitos da Lei Federal n० 11.794, de 8 de outubro de 2008, do Decreto Federal $n^{\circ} 6.899$, de 15 de julho de 2009, e das normas editadas pelo Conselho Nacional de Controle de Experimentação Animal (CONCEA), e foi aprovada pela Comissão de Ética no Uso de Animais (CEUA) da Faculdade de Ciências Farmacêuticas da Universidade de São Paulo (FCF/USP), em reunião de 11 de maio de 2018.

\begin{tabular}{|l|l|}
\hline Finalidade & Pesquisa Científica \\
\hline Vigência da autorização & $01 / 06 / 2018$ a 31/07/2019 \\
\hline Espécie/linhagem/raça & Camundongo isogênico (Mus musculus) BALB/c \\
\hline Número de animais & 20 \\
\hline Sexo & Macho \\
\hline Peso/ldade & $20 g ; 21$ dias \\
\hline Origem & Biotério - USP \\
\hline
\end{tabular}

Conforme a legislação vigente, deverá ser apresentado, no encerramento do projeto de pesquisa, o respectivo relatório final.

São Paulo, 11 de maio de 2018.

\author{
Profa. Dra. Neuza Mariko Aymoto Hassimotto \\ Coordenadora da CEUAFCF/USP
}

